\title{
Atmospheric chemistry in the Arctic and subarctic: Influence of natural fires, industrial emissions, and stratospheric inputs
}

\section{Citation}

Wofsy, S. C., G. W. Sachse, G. L. Gregory, D. R. Blake, J. D. Bradshaw, S. T. Sandholm, H. B. Singh, et al. 1992. "Atmospheric Chemistry in the Arctic and Subarctic: Influence of Natural Fires, Industrial Emissions, and Stratospheric Inputs." Journal of Geophysical Research 97 (D15): 16731. doi:10.1029/92jd00622.

\section{Published Version}

doi:10.1029/92JD00622

\section{Permanent link}

http://nrs.harvard.edu/urn-3:HUL.InstRepos:14121815

\section{Terms of Use}

This article was downloaded from Harvard University's DASH repository, and is made available under the terms and conditions applicable to Other Posted Material, as set forth at http:// nrs.harvard.edu/urn-3:HUL.InstRepos:dash.current.terms-of-use\#LAA

\section{Share Your Story}

The Harvard community has made this article openly available.

Please share how this access benefits you. Submit a story.

Accessibility 


\title{
Atmospheric Chemistry in the Arctic and Subarctic: Influence of Natural Fires, Industrial Emissions, and Stratospheric Inputs
}

\author{
S. C. WOFSY' , G. W. SACHSE ${ }^{2}$, G. L. GREGORY ${ }^{2}$, D. R. BLAKE ${ }^{3}$, J. D. BRADSHAW ${ }^{4}$, \\ S. T. SANDHOLM ${ }^{4}$, H. B. SINGH' J. A. BARRICK ${ }^{2}$, R. C. HARRISS ${ }^{2,6}$, R. W. TALBOT ${ }^{2,6}$, \\ M. A. SHIPHAM ${ }^{2}$, E. V. BROWELL ${ }^{2}$, D. J. JACOB ${ }^{1}$, AND J. A. LOGAN ${ }^{1}$
}

\begin{abstract}
Haze layers with perturbed concentrations of trace gases, believed to originate from tundra and forest wild fires, were observed over extensive areas of Alaska and Canada in 1988. Enhancements of $\mathrm{CH}_{4}, \mathrm{C}_{2} \mathrm{H}_{2}, \mathrm{C}_{2} \mathrm{H}_{6}$. $\mathrm{C}_{3} \mathrm{H}_{8}$, and $\mathrm{C}_{4} \mathrm{H}_{10}$ were linearly correlated with $\mathrm{CO}$ in haze layers, with mean ratios (mole hydrocarbon/mole $\mathrm{CO})$ of $0.18( \pm 0.04(1 \quad \sigma)), 0.0019( \pm 0.0001), 0.0055( \pm 0.0002), 0.0008( \pm 0.0001)$, and 1.2 $\times 10^{-4}\left( \pm 0.2 \times 10^{-4}\right)$, respectively. Enhancements of $\mathrm{NO}_{y}$ were variable, averaging $0.0056( \pm 0.0030)$ mole $\mathrm{NO}_{y} /$ mole $\mathrm{CO}$, while perturbations of $\mathrm{NO}_{x}$ were very small, usually undetectable. At least $1 / 3$ of the NOy in the haze layers had been converted to peroxyacetyl nitrate (PAN), representing a potential source of NOx to the global atmosphere; much of the balance was oxidized to nitrate ( $\mathrm{HNO}_{3}$ and particulate). The composition of subArctic haze layers was consistent with aged emissions from smoldering combustion, except for $\mathrm{CH}_{4}$, which appears to be partly biogenic. Inputs from the stratosphere and from biomass fires contributed major fractions of the $\mathrm{NO}_{y}$ in the remote sub-Arctic troposphere. Analysis of aircraft and ground data indicates relatively little influence from mid-latitude industrial $\mathrm{NO}_{\mathrm{y}}$ in this region during summer, possibly excepting transport of PAN. Production of $\mathrm{O}_{3}$ was inefficient in sub-Arctic haze layers, less than $0.1 \mathrm{O}_{3}$ molecules per molecule of $\mathrm{CO}$, reflecting the low $\mathrm{NO}_{z} / \mathrm{CO}$ emission ratios from smoldering combustion. Mid-latitude pollution produced much more $\mathrm{O}_{3}, 0.3-0.5 \mathrm{O}_{3}$ molecules per molecule of $\mathrm{CO}$, a consequence of higher $\mathrm{NO}_{x} / \mathrm{CO}$ emission ratios.
\end{abstract}

\section{INTRODUCTION}

The Arctic and sub-Arctic regions of Alaska, Canada, and Greenland represent a vast wildemess with extremely low levels of human activity, one of the largest such land areas remaining in the world. Anthropogenic emissions are negligible over most of the region, except for oil operations on the North Slope [Blake et al., this issue]. Atmospheric composition is regulated mainly by natural processes and by long-range transport of pollution. Natural influences include stratosphere-troposphere exchange [Gregory et al., this issue; Browell et al., this issue], tundra and forest wild fires, and uptake of reactive chemical species by vegetation [Jacob et al., this issue]. Anthropogenic pollutants have been observed at particularly high levels in late winter and spring, during the "Arctic haze" period [Rahn, 1981; Rahn and McCaffrey, 1980; Barrie and Hoff, 1985; Hansen et al., 1989].

Natural fires occur throughout the boreal zone during summer, representing a potentially dominant source of hydrocarbons, $\mathrm{NO}_{\mathbf{x}}$, and particulates. Most previous studies of fires have focussed on mid-latitudes or on tropical burning [e.g., Hegg et al., 1990; Seiler and Crutzen, 1980, Andreae et al., 1988; Crutzen et al., 1985; Ward and Hardy, 1991; Greenberg et al., 1984; Cofer et al.,

\footnotetext{
${ }^{1}$ Division of Applied Science and Department of Earth and Planetary Science, Harvard University, Cambridge, Massachusetts.

${ }^{2}$ NASA Langley Research Center, Hampton, Virginia.

${ }^{3}$ Department of Chemistry, University of Califomia at Irvine.

${ }^{4}$ School of Earth and Atmospheric Science, Georgia Institute of Technology, Atlanta.

5 NASA Ames Research Center, Moffert Field, Califomia.

${ }^{6}$ Present address: Complex Systems Research Center, University of New Hampshire, Durham.
}

Copyright 1992 by the American Geophysical Union.

Paper number 92JD00622.

0148-0227/92/92JD00622\$05.00
1988], with only a few investigations in the boreal zone [Cofer et al., 1989].

The present paper investigates layers with enhanced concentrations of trace gases intercepted by the NASA Electra aircraft over Alaska during the Arctic Boundary Layer Expedition (ABLE 3A) in July-August 1988. The summer of 1988 was notably hot and dry over Alaska and the haze layers are believed to have originated from natural fires that were widespread in the region [Shipham et al., this issue]. Data from the haze layers are examined to define primary emission factors from boreal wild fires and to delineate the course of chemical aging. The chemical signatures of these haze layers are found to be remarkably consistent with emissions from smoldering combustion observed in the laboratory [Lobert et al., 1991], and notably different from emissions from flaming combustion.

We also assess the relative importances of natural and anthropogenic sources in regulating trace gas concentrations over southern Alaska. Analysis of data for background air indicates that input from the stratosphere provided a dominant source for $\mathrm{O}_{3}$ [Gregory et al., this issue]. We argue that the stratosphere provided a significant source for $\mathrm{NO}_{\mathrm{y}}$ and that natural fires were also important. Long-range transport of pollution from mid-latitudes may have affected vertical distributions of $\mathrm{C}_{2}-\mathrm{C}_{4}$ alkanes and $\mathrm{CO}$ but could not be detected unambiguously for $\mathrm{NO}_{y}$ or $\mathrm{O}_{3}$.

\section{SUMMERTIME HAZE LAYERS IN THE SUB-ARCTIC}

Plate 1 shows lidar images from several flights during ABLE $3 \mathrm{~A}$, and Figure 1 shows the corresponding flight paths and locations of fires on the day of Flights 14 and 20/21. Flight 14, on July 26, 1988 (Plate 1a), shows an extensive haze layer between 2 and $3 \mathrm{~km}$ altitude, as indicated by dark areas in the aerosol image. This layer was sampled near 2-km and again at 4-km altitude in a vertical profile at point 2 (see Figure 2). Weak ozone enhancement may have been associated with the aerosol layer (for example, examine the lidar data near Point 1). A fire covering several square kilometers was burning about $100 \mathrm{~km}$ to the north, and a number of very large fires were burning to the east; visibility had 
8

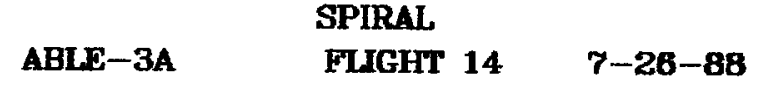

AEROSOL DISTRIBUTION
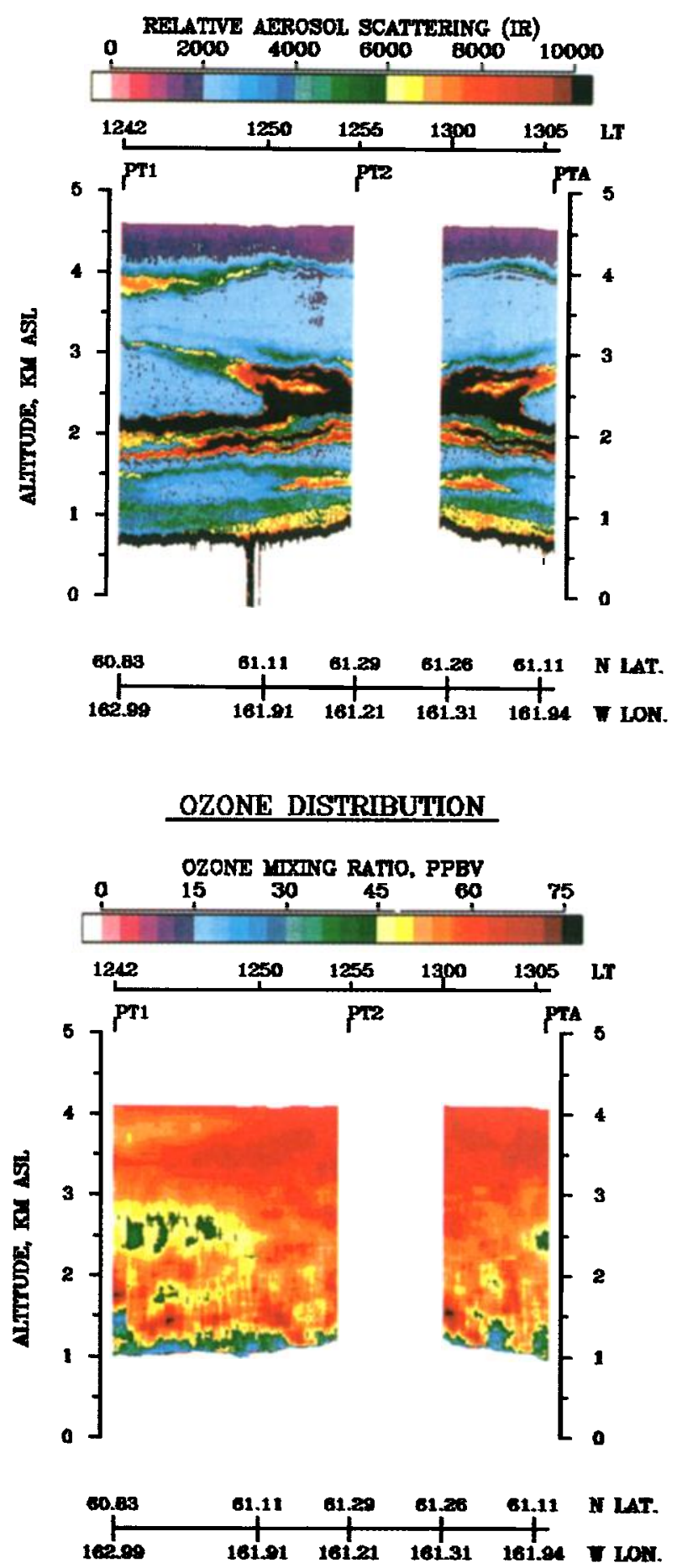

Plate 1. LIDAR images of acrosol extinction at $1 \mu \mathrm{m}$ (upper panels) and ozone mixing ratio (lower panels) for (a) Flight 14 (July 26, 1988, and (b) Flight 21 (August 4, 1988), showing haze layers in the region near Bethel,
6

ABLE 3A FLIGHT $21 \quad 8-4-88$
AEROSOL DISTRIBUTION

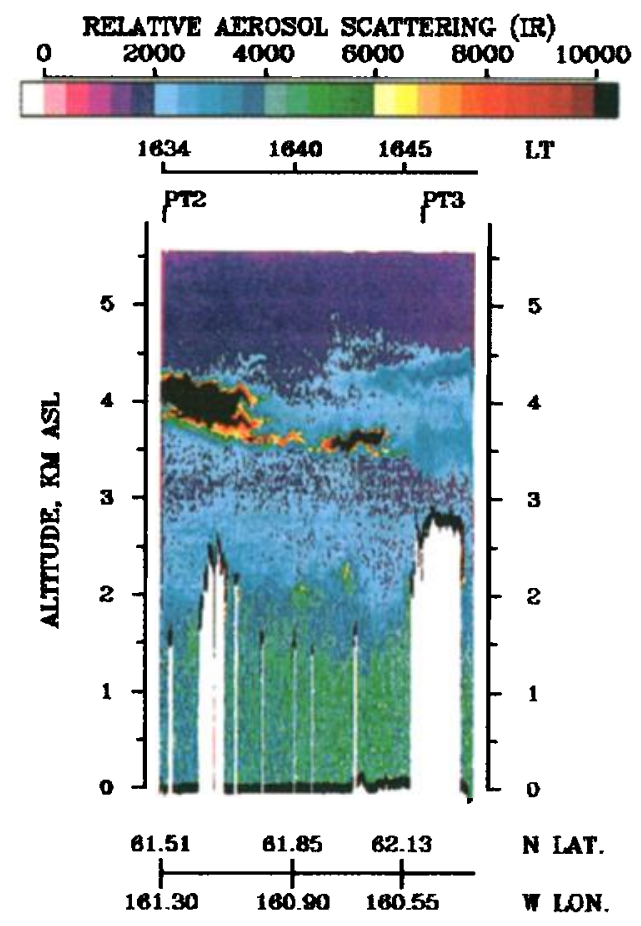

O'ZONH: DIS"I'LIHUI'LON

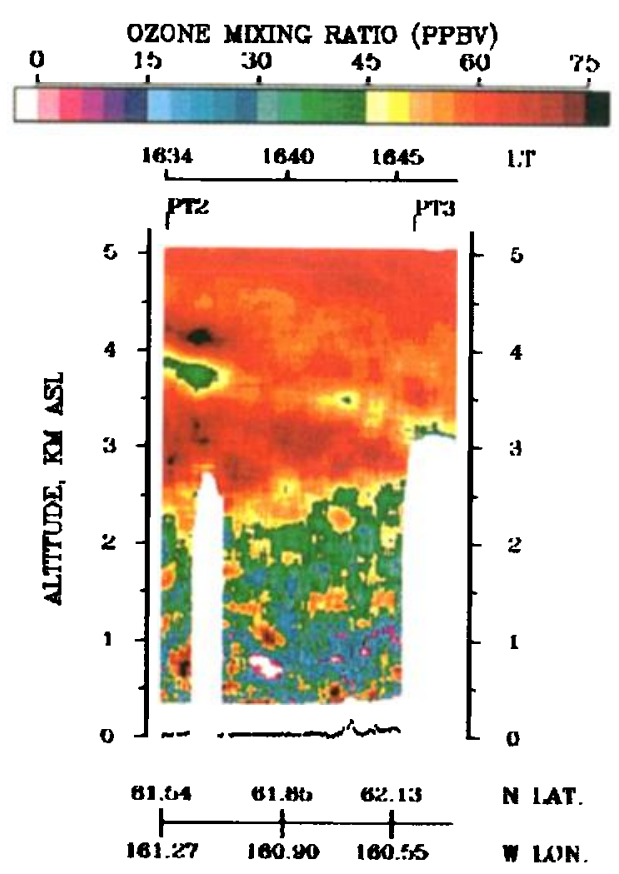

Alaska. (c) Data for Flight 33 (August 17, 1988) cover the coastal transect from Portland, Maine, to Wallops Island, Virginia.

'mertime Arctic troposphere observations related to $\mathrm{N}_{x} \mathrm{O}_{y}$ distribution and partitioning: ABLE 3A, submitted to Journal of Geophysical Research, 1991) for experimental detail) was observed (see

Figure 2 and Table 1), indicating relatively recent emissions, and been reduced by smoke during the previous few days in Bethel [Shipham et al., this issue]. The high aerosol burden suggests that a biomass fire was the main source; however the origin cannot be uniquely traced. Elevated $\mathrm{NO}_{x}$ (see S.T. Sandholm et al., Sum- 
c

$$
\begin{gathered}
\text { PORTLAND - LANGLEY } \\
\text { ABLE-3A } \quad \text { FLIGHT 33 8-17-88 } \\
\text { AEROSOL DISTRIBUTION }
\end{gathered}
$$
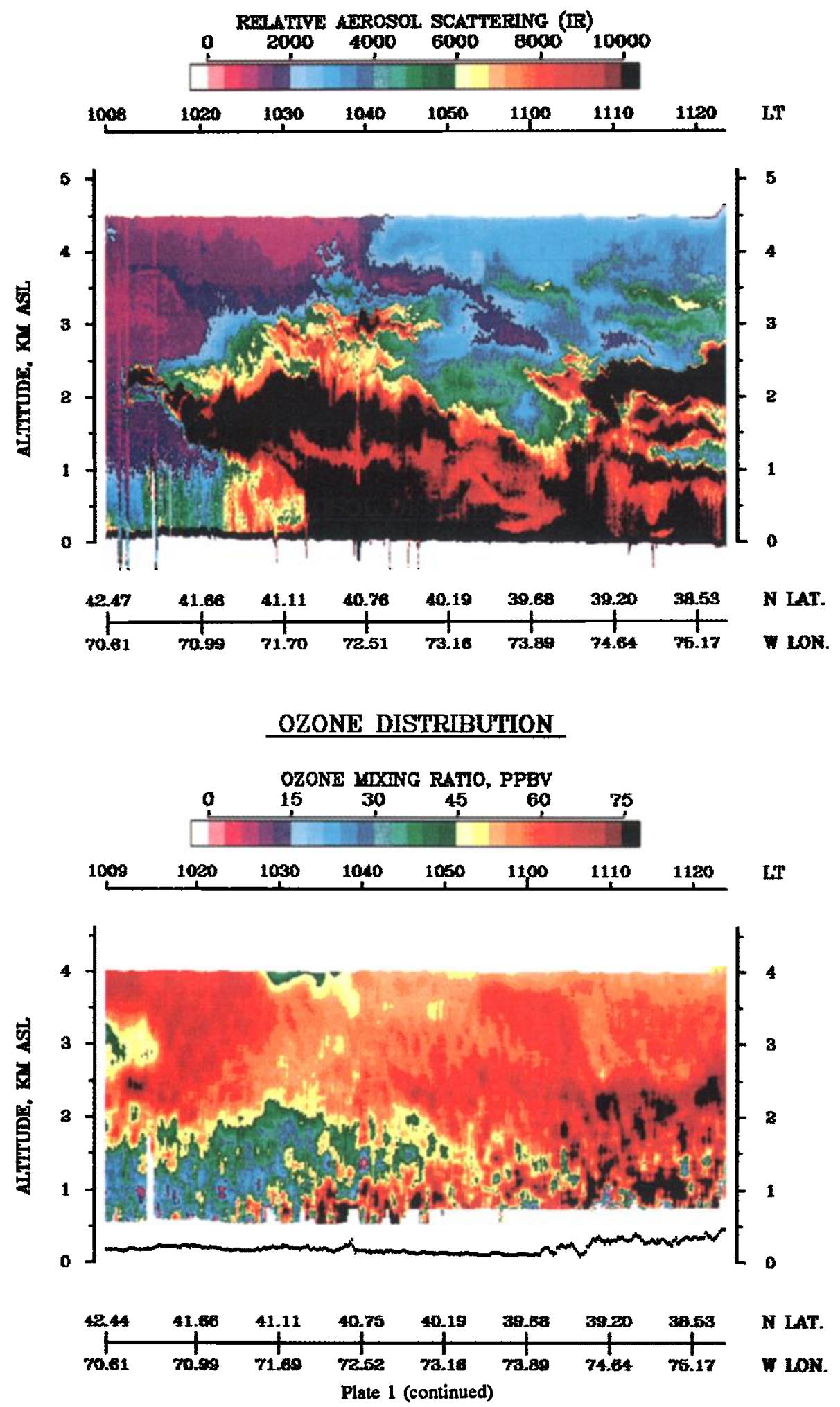

the town of Bethel (population 4000, $30-100 \mathrm{~km}$ distant) may Back trajectories passed over numerous and extensive fires identihave contributed. fied in satellite images $200-1000 \mathrm{~km}$ to the east and northeast

On Flights 20 and 21 (August 3, 1988) a haze layer was ob- (see Figures 34 and 35 in Shipham et al. [this issue]. Enhanceserved between 3 and $4.5 \mathrm{~km}$ altitude (Plate $1 b$ and Figure 3). ments of $\mathrm{CO}$ and $\mathrm{C}_{2}$ hydrocarbons were similar on Flights 14 and 


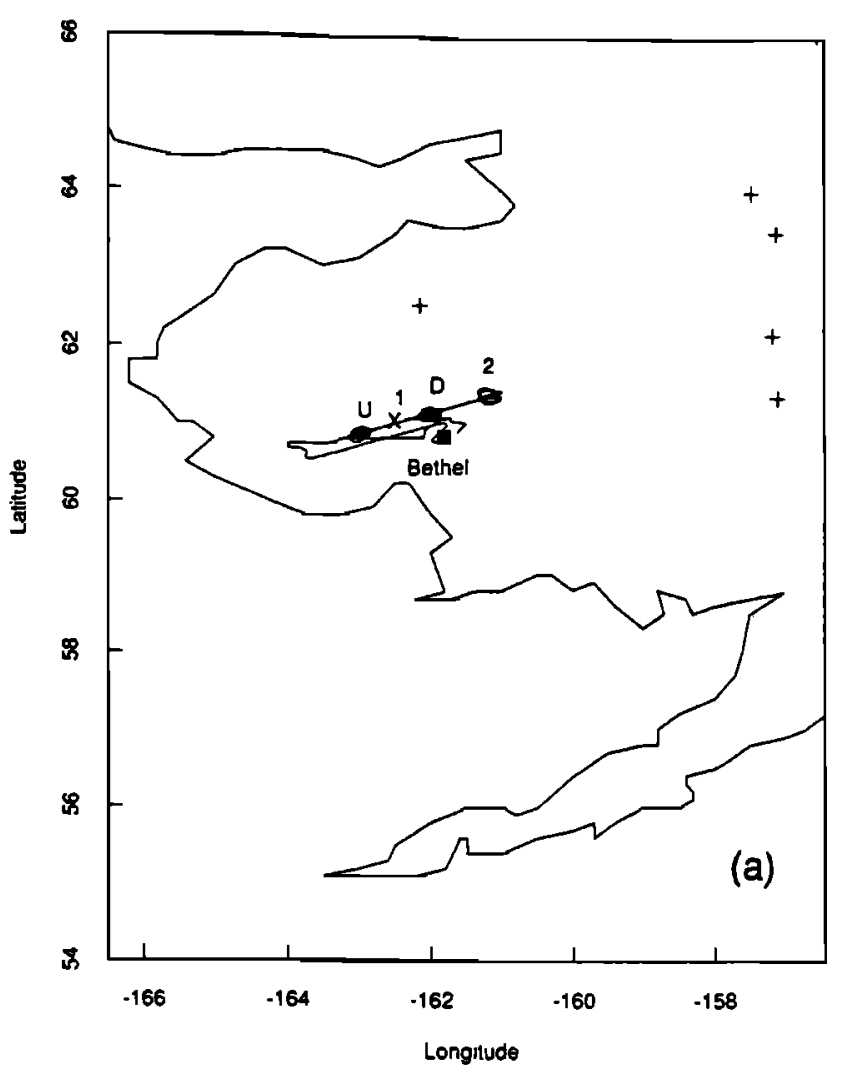

Fig. 1. Flight tracks for (a) Flight 14 and (b) Fight 20/21 near Bethel, Alaska, and (c) Flight 33 along the east coast of the United States. The numbers correspond to points in the LIDAR images in Plate 1. The locations of spirals are indicated by D (first spiral, descending) and $U$ (second spiral, ascending). The tower site is denoted by $\mathbf{X}$; locations of major active fires by crosses. The arrow denotes direction of motion of air parcels from trajectory calculations for Flights 20/21 [Shipham et al., this issue], for the $300 \mathrm{~K}$ level (close to the haze layer altitude).

20/21, but NO was not perturbed and $\mathrm{NO}_{\text {y }}$ was only slightly elevated on Flights 20/21.

Carbon monoxide, measured continuously by the differential absorption CO measurement (DACOM) instrument [Harriss et al., this issue], provides the most sensitive indicator for combustion, to which other concentrations may be ratioed to obtain emission factors. Correlations between $\mathrm{CO}$ and $\mathrm{C}_{2} \mathrm{H}_{6}$, and between $\mathrm{CO}$ and $\mathrm{C}_{2} \mathrm{H}_{2}$, were remarkably uniform for the haze layers. Figure 4 shows linear regressions for composite data from Flights 14, 20 and 21 (20 grab samples analyzed for hydrocarbons [Blake et al., this issue]), giving $r^{2}=0.97$ for both, i.e., linear dependence on CO could account for $97 \%$ of the variance observed for $\mathrm{C}_{2} \mathrm{H}_{2}$ and $\mathrm{C}_{2} \mathrm{H}_{6}$. Propane was more variable than acetylene and ethane, relative to $\mathrm{CO}$, but a significant correlation $\left(r^{2}=0.82\right)$ was still obtained in the composite data set (Figure $4 c$ ) and for individual haze layers (see Table 1). The uniformity of hydrocarbon/CO ratios in Flights 14 and 20/21 argues strongly for a similar origin for haze layers encountered on these flights.

Concentrations of butane were not correlated with $\mathrm{CO}$ in the composite set, however consistent correlations, with similar proportionality coefficients, were found in individual layers (Table 1). The variable results likely reflect the difficulty in making measurements at very low concentrations, and atmospheric losses could also play a role. The lifetime for $\mathrm{C}_{4} \mathrm{H}_{10}$ is only a few hours in the
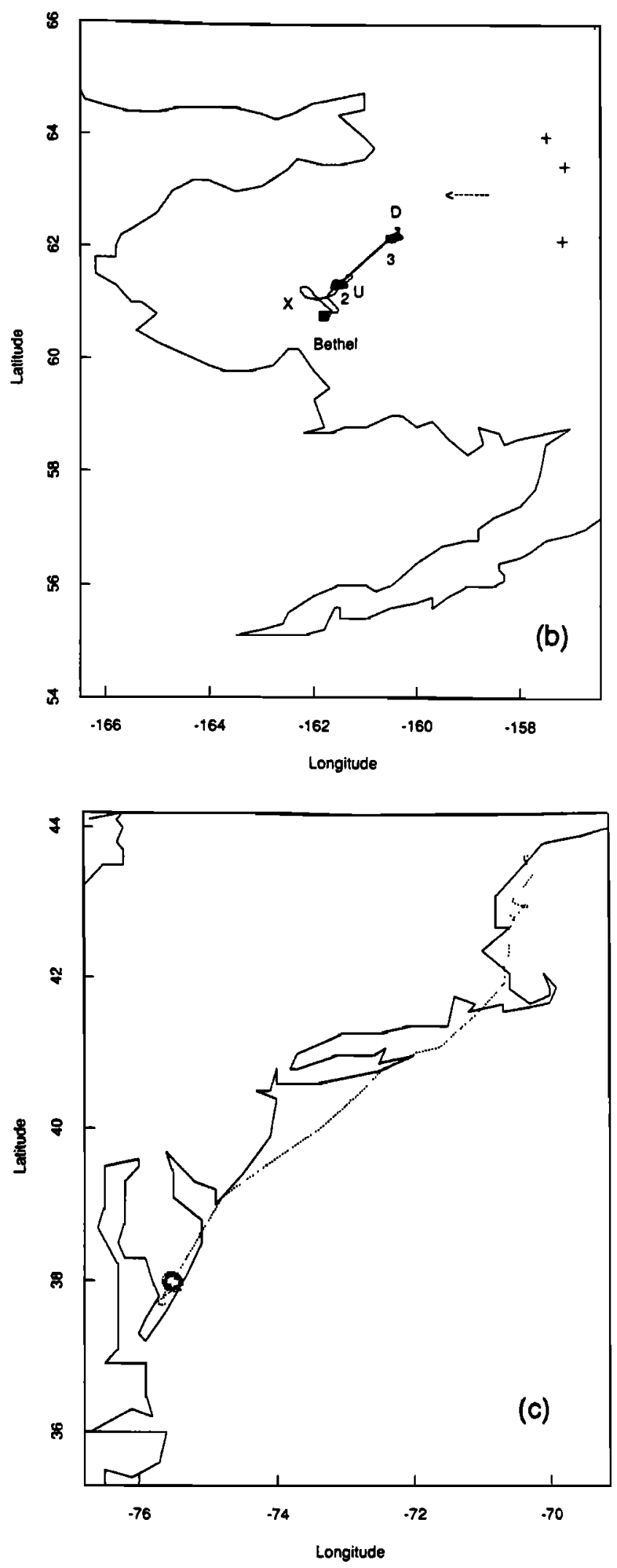

daytime, and layers more than a day old might lose the signature of primary emissions.

We define emission factors from fires by focussing on haze layers with well-defined boundaries, believed to represent fire plumes. Primary emission ratios are preserved within the haze 

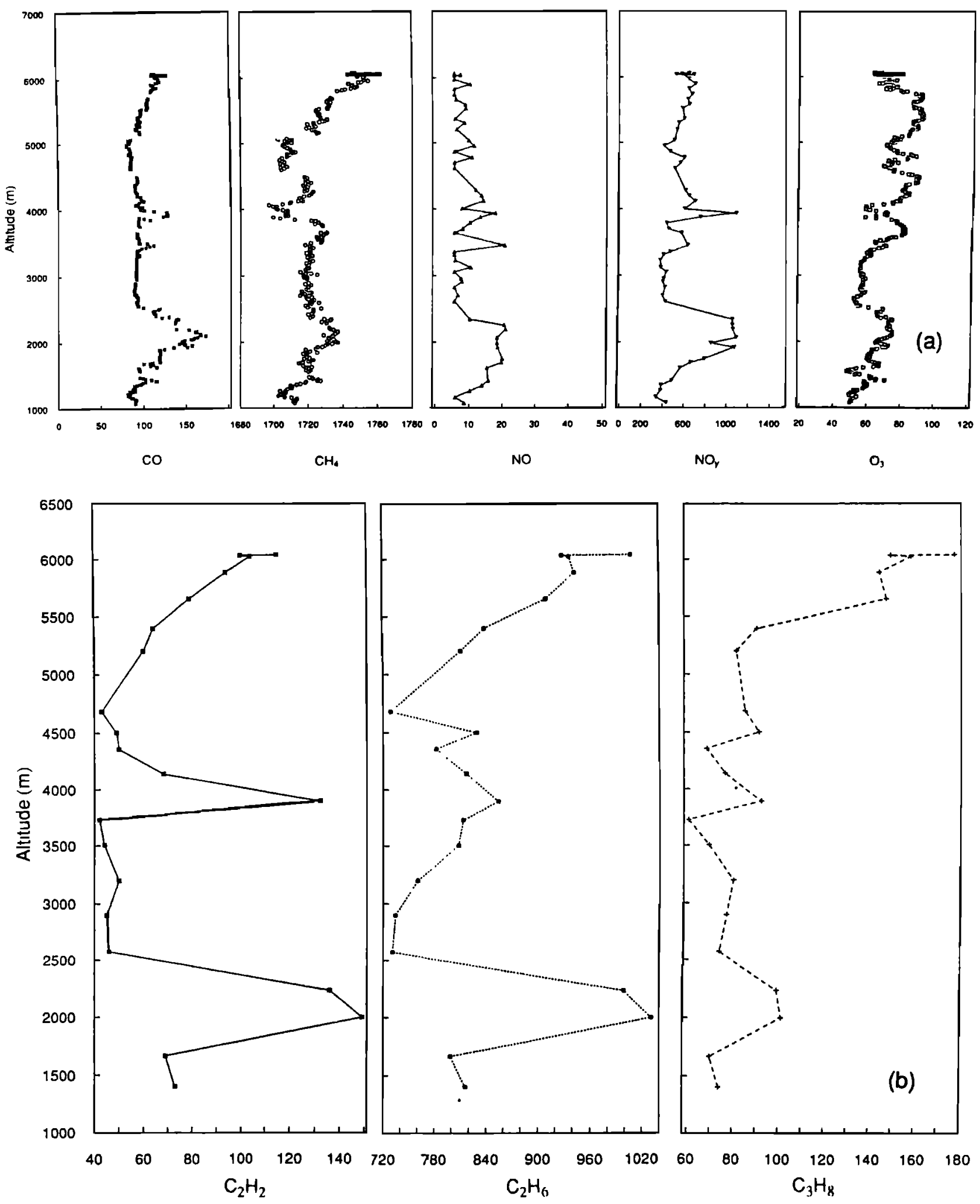

Fig. 2. Vertical profiles for trace gases on Flight 14, at Point U (spiral 2) in Plate 1a. Data for $\mathrm{CO}, \mathrm{CH}_{4}$ and $\mathrm{O}_{3}$ represent 10-s averages; data for $\mathrm{NO}$ and $\mathrm{NO}_{\mathrm{y}}$ are 1-min averages, and data for nonmethane hydrocarbons represent grab samples.

layer as clean air is entrained. The uniform ratios obtained for $\mathrm{C}_{2} \mathrm{H}_{2}$ and $\mathrm{C}_{2} \mathrm{H}_{6}$ support the validity of this framework.

21) and over the Bering Sea (Flight 23). Linear correlations

Table 1 summarizes observations of trace gas concentrations in between trace gases and $\mathrm{CO}$ were derived from the slope of the rehaze layers encountered in the Bethel region (Flights 14, 20, and background obtained by linear interpolation between altitude lim- 

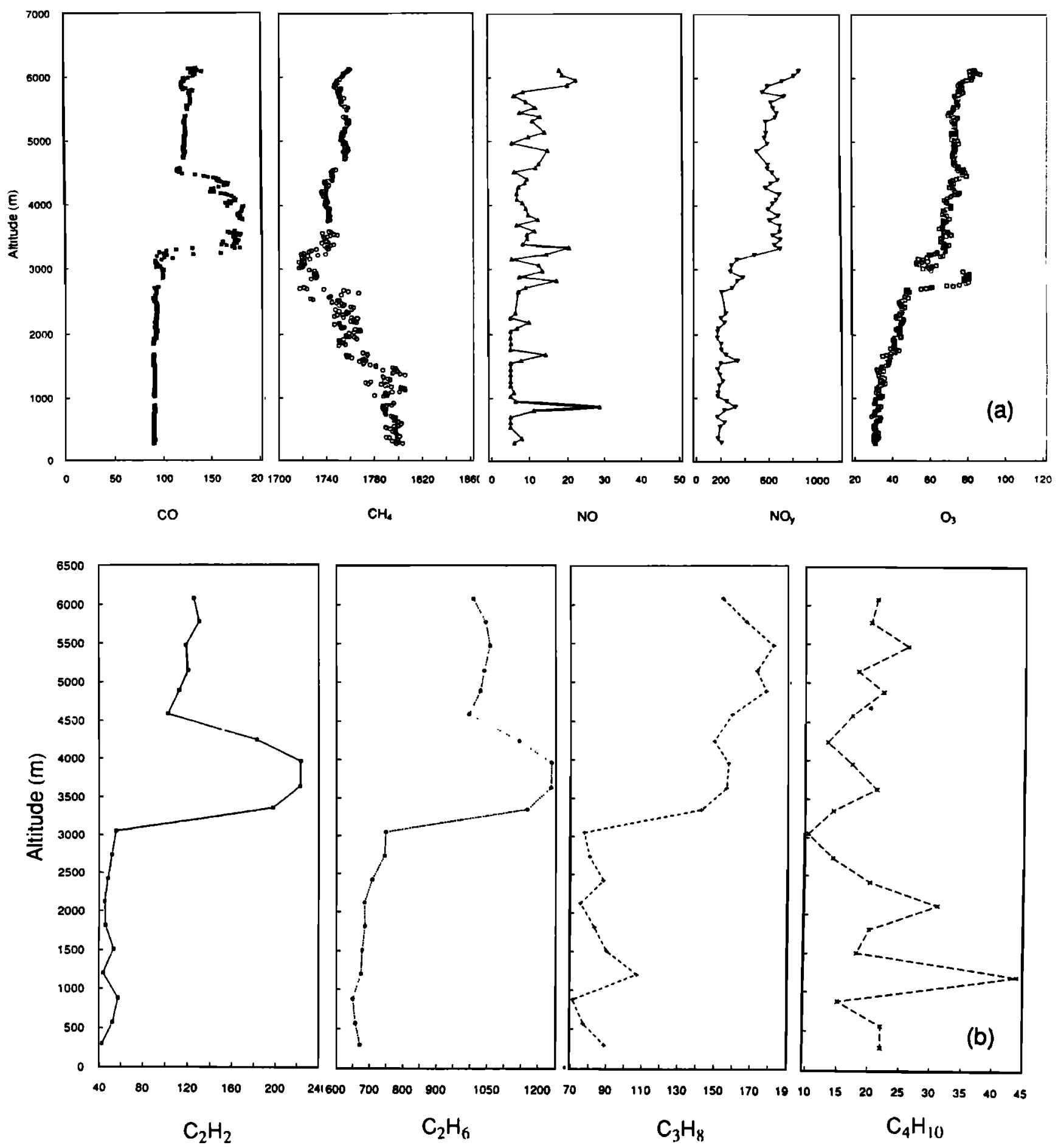

Fig. 3. ( $a$ and $b$ ) Vertical profiles on Flight 21 at Point 3 (descending) in Plate $1 b$. ( $c$ and $d$ ) Profiles on Flight 21 at point 2 (ascending) in Plate $1 b$.

its for the polluted layer defined by the CO enhancement. For of $r^{2}$ for $\mathrm{O}_{3}$ were relatively low, and ratios $\Delta \mathrm{O}_{3} / \Delta C O$ were varieach intercepted layer, results for two profiles were averaged (des- able.

cending and ascending spirals).

Relationships between $\mathrm{CO}$ and nonmethane hydrocarbons were

Examples of regressions against $\triangle \mathrm{CO}$ are given in Figure 5 for remarkably consistent with laboratory data for smoldering the vertical profile at Pt. D on Flight 14 (Plate 1a). Values of $r^{2}$ combustion of biomass material [Crutzen and Andreae, 1990; for hydrocarbons and NO, typically exceeded 0.7 and in many Cofer et al., 1989; Lobert et al., 1991]. In fact, observed ratios cases, were larger than 0.9. Small enhancements of NO were ob- fell within $10 \%$ of laboratory means for $\mathrm{C}_{2} \mathrm{H}_{2} / \mathrm{CO}$ and $\mathrm{C}_{2} \mathrm{H}_{6} / \mathrm{CO}$. served for Flights 14 and 23, but none for Flights 20/21. Values Laboratory data for flaming combustion show more than 3 times 

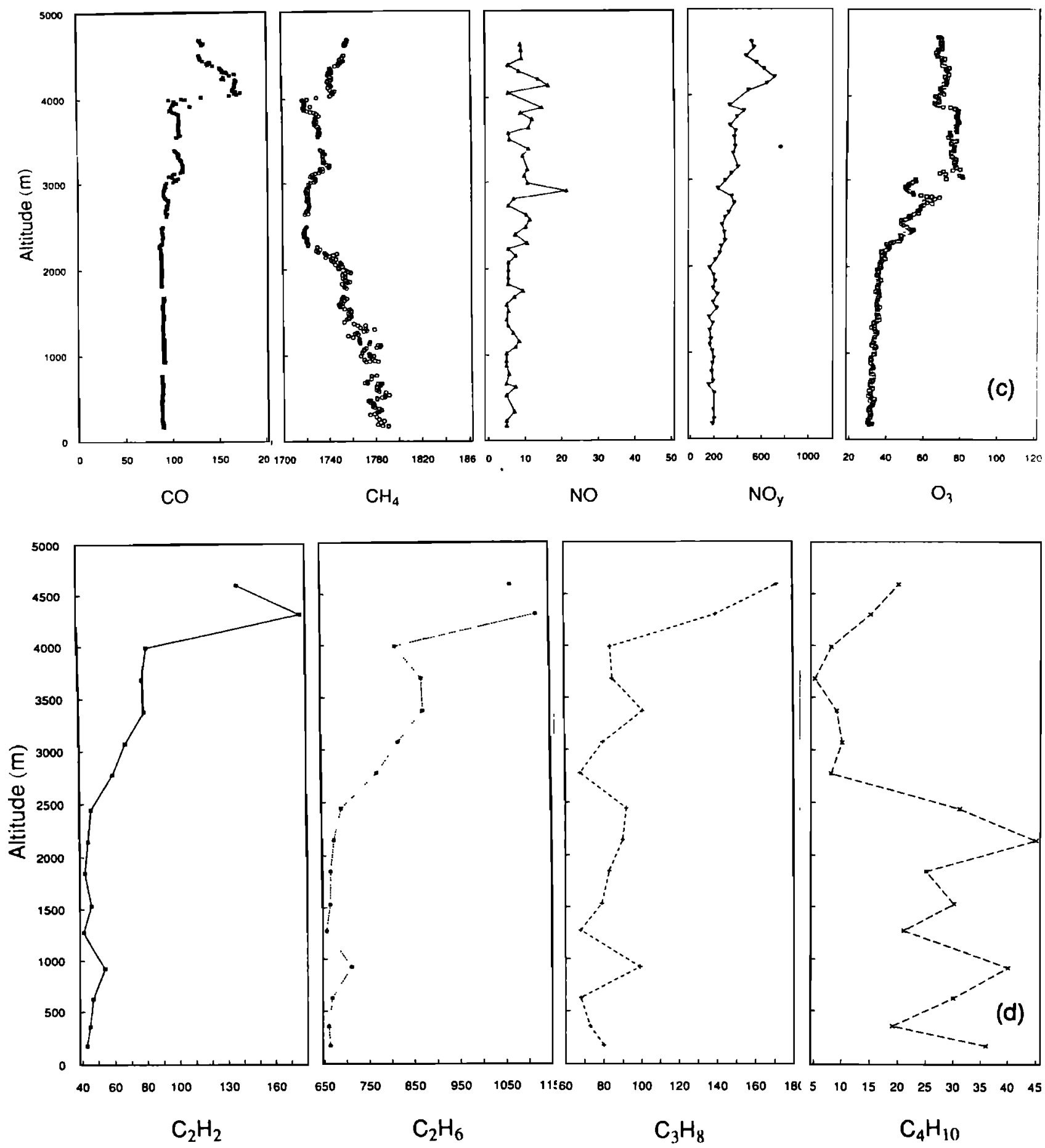

Fig. 3. (continued)

higher emissions of $\mathrm{C}_{2} \mathrm{H}_{2}$, and 3 times lower of $\mathrm{C}_{2} \mathrm{H}_{6}$, relative to CO [Lobert et al., 1991].

Arctic haze layers contained less $\mathrm{NO}_{\mathrm{y}}$ than observed in association with fires in the Amazon or at mid-latitudes (see Table 1a), consistent with a dominant role for smoldering combustion. Most $\mathrm{NO}_{y}$ from biomass fires evolves during flaming combustion, by oxidation of fuel nitrogen [Lobert et al., 1991]. Arctic vegetation is notably low in nitrogen [Chapin and Shaver, 1985]. The variance of $\mathrm{NO}_{y}$ ratios to $\mathrm{CO}$ suggests variable contributions from small areas of flaming combustion. Background levels of $\mathrm{NO}_{y}$ are very low in the Arctic, and the small yields of NOy from tundra fires can nevertheless represent a significant source.

Enhancements of ozone are small in the haze layers, even negative in some, reflecting the low $\mathrm{NO}_{x}$ emissions typical of smoldering fires [Jacob et al., this issue]. Significant positive correlation between $\mathrm{O}_{3}$ and $\mathrm{CO}$ was observed only in a layer with detectable enhancement of $\mathrm{NO}_{x}$ and relatively high $\Delta \mathrm{NO}_{y} / \Delta \mathrm{CO}$ (Flight 14). The small values for $\Delta \mathrm{O}_{3} / \Delta \mathrm{CO}$ in Arctic haze layers, about 0.1 (Table 1a), may be contrasted with values averaging 0.4 in urban/industrial pollution (Table 2 and Figure 7). 


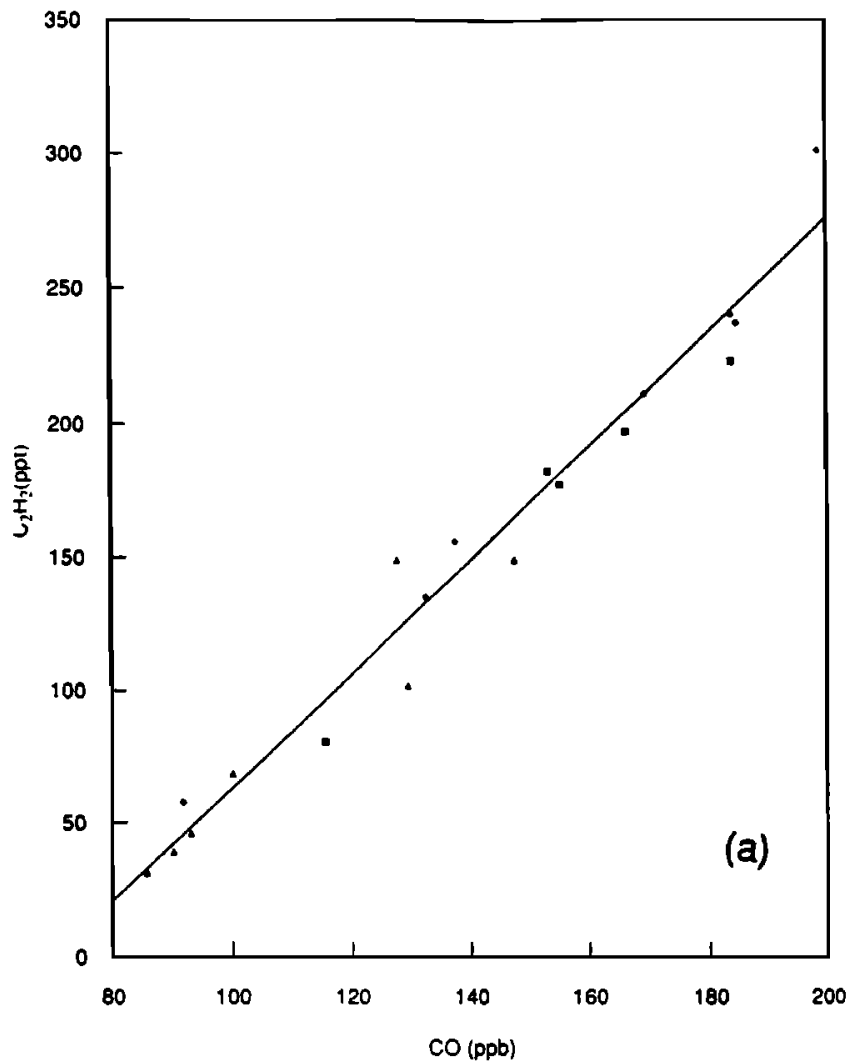

Fig. 4a. (a) Relationship between $\mathrm{CO}$ (ppb) and $\mathrm{C}_{2} \mathrm{H}_{2}$ (ppt) obtained from composited data for haze layers from Flights 14 (triangle), 20 (diamond) and 21 (square). The regression line shown, with slope $0.0021( \pm 0.03)$ mole $\mathrm{C}_{2} \mathrm{H}_{2}$ per mole $\mathrm{CO}$, gives $r^{2}=0.97$.

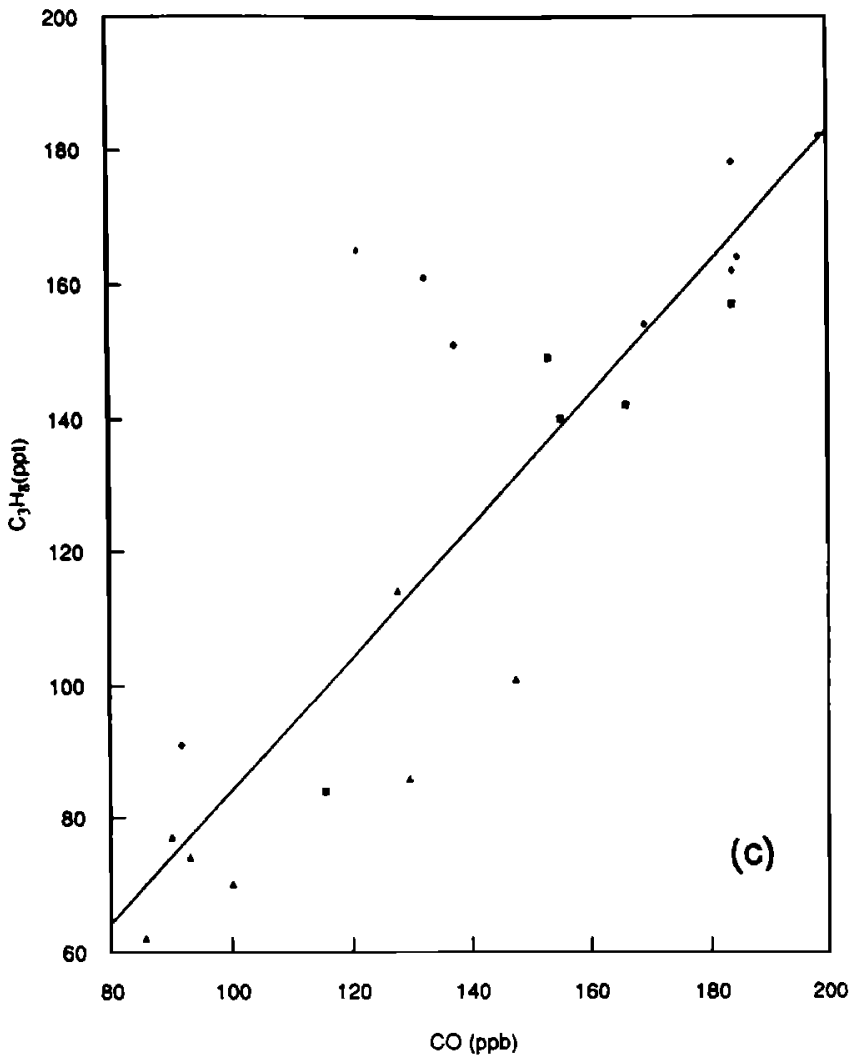

Fig. 4c. Same as for Figure 4a, for $\mathrm{C}_{3} \mathrm{H}_{8}$. Regression has slope 0.0010 ( \pm 0.002 ) mole/mole, $r^{2}=0.82$.

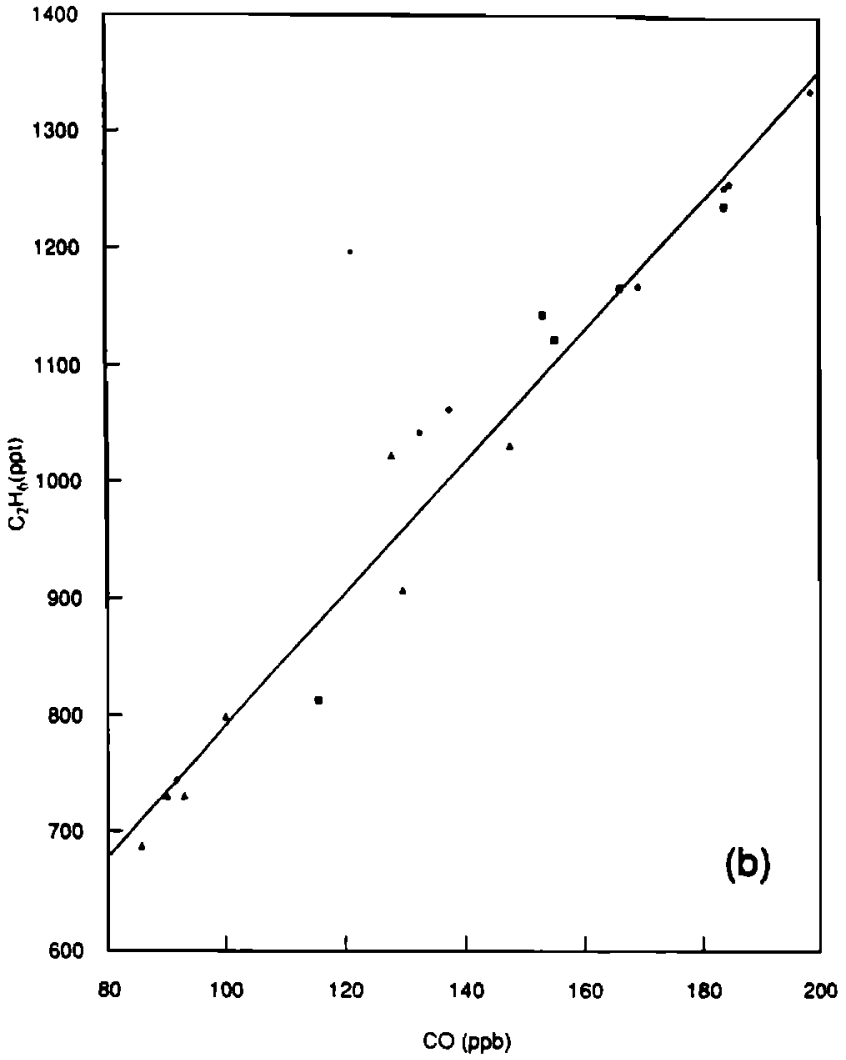

Fig. 4b. Same as for Figure 4a, for $\mathrm{C}_{2} \mathrm{H}_{6}$. Regression has slope 0.0055 (t 0.002 ) $\mathrm{mole} / \mathrm{mole}, r^{2}=0.96$.

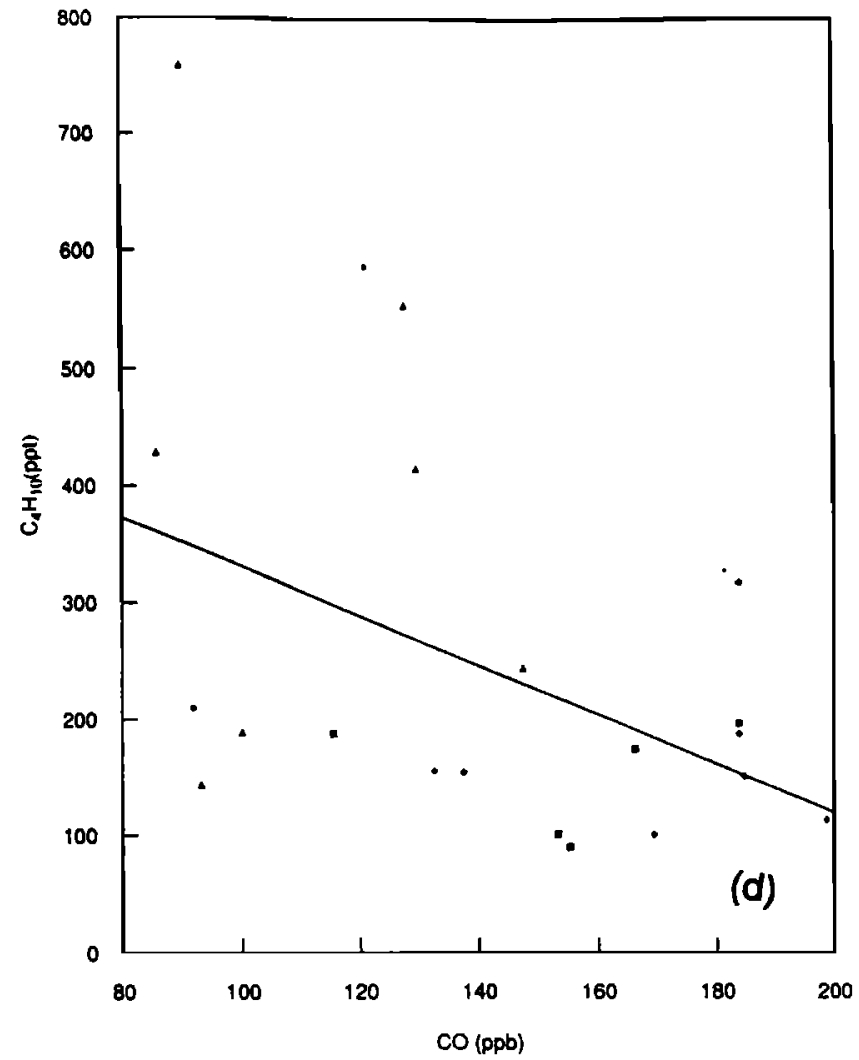

Fig. 4d. Same as for Figure $4 a$, for $\mathrm{C}_{4} \mathrm{H}_{10}$. Regression is not statistically valid. 
TABLE 1a. Enhancement Ratios in Biomass Buming and Pollution Plumes

\begin{tabular}{cccccccccc}
\hline Flight & $\mathrm{NO}_{\mathrm{y}}$ & $\mathrm{NO}$ & $\mathrm{C}_{2} \mathrm{H}_{2}$ & $\mathrm{C}_{2} \mathrm{H}_{6}$ & $\mathrm{C}_{3} \mathrm{H}_{8}$ & $\mathrm{C}_{4} \mathrm{H}_{10}$ & $\mathrm{CH}_{4}$ & $\mathrm{O}_{3}$ & PAN \\
\hline 14(Bethel) & 0.0084 & 0.0003 & 0.0020 & 0.0057 & 0.0006 & 0.00011 & 0.23 & 0.175 & 0.31 \\
20(Bethel) & 0.0036 & $<0.00002$ & 0.0019 & 0.0054 & 0.0008 & 0.00010 & 0.17 & $(0.076)$ & 0.23 \\
21(Bethel) & 0.0032 & $<0.0001$ & 0.0019 & 0.0055 & $(0.0009)$ & 0.00015 & 0.19 & $(0.040)$ & 0.38 \\
Mean & 0.0056 & $<0.0001$ & 0.0019 & 0.0055 & 0.0008 & 0.00012 & 0.18 & 0.095 & 0.30 \\
Bethel & \pm 0.0003 & & \pm 0.0001 & \pm 0.0002 & \pm 0001 & \pm 00002 & \pm .04 & \pm 0.06 & \pm 0.05 \\
23(Bering) & 0.023 & 0.0002 & 0.0020 & 0.0096 & 0.0043 & 0.0046 & 0.41 & 0.137 & NA \\
29(80) & - & - & - & - & - & - & 0.44 & -0.9 & - \\
Amazon* & 0.016 & 0.014 & $0.03 \dagger$ & 0.007 & 0.0014 & $\mathrm{NA}$ & 0.08 & $0.056(.042 \ddagger)$ & NA \\
N. America* & 0.042 & 0.042 & 0.0026 & 0.00516 & 0.00264 & 0.0011 & 0.032 & 0.037 & \\
\hline
\end{tabular}

All ratios are given relative to $\mathrm{CO}$ (mole/mole) except PAN, which is ratioed to NO . Flights 14, 20, 21 were near Bethel, Alaska, Flight 23 over the Bering Sea, Flight 29 over polar sea ice north of Greenland. Proportionality coefficients were computed by averaging results for two plume encounters on each flight. "Mean Bethel" is the average of the coefficients from individual flights. Marginally significant correlations are given in parentheses. $\mathrm{C}_{2} \mathrm{H}_{2}: \mathrm{C}_{2} \mathrm{H}_{6}=0.3$ (in Anchorage, $\mathrm{C}_{2} \mathrm{H}_{2}: \mathrm{C}_{2} \mathrm{H}_{6}=1.15$ ).

*Previous data for forest and savanna fires. Mean values for the Amazon from Andreae et al. [1988] for NO and NO, (computed as 4 ( $\Delta \mathrm{NO} / \Delta \mathrm{CO}$ ) for fresh plumes) and from Greenberg et al. [1984] for hydrocarbons. Data for forest and brush fires in the United States and Canada from Hegg et al. [1990], with $\mathrm{NO}_{x}-\mathrm{NO}_{y}$ assumed in fresh plumes.

†For all alkynes, from Greenberg et al. [1984].

$¥$ The $\frac{\Delta \mathrm{O}_{3}}{\Delta \mathrm{CO}}$ ratio in heavy pollution over the cerrado was 0.056 [Greenberg et al., 1984], the average value was lower $(0.042 \pm .030)$ in aged plumes over the Amazon Basin [Andreae et al., 1988].

TABLE 1b. Acid and Aerosol Concentrations (pptv) in Plumes and Background

\begin{tabular}{lrcrrrrrrrrr}
\hline & \multicolumn{3}{c}{ Gaseous Acids } & \multicolumn{9}{c}{ Aerosol Components } \\
\hline \multicolumn{1}{c}{ Flight } & \multicolumn{1}{c}{$\mathrm{HNO}_{3}$} & $\mathrm{HCOOH}$ & $\mathrm{CH}_{3} \mathrm{COOH}$ & $\mathrm{NO}_{3}^{-}$ & $\mathrm{SO}_{4}^{-}$ & $\mathrm{C}_{2} \mathrm{O}_{4}^{-}$ & $\mathrm{MSA}^{*}$ & $\mathrm{Na}^{+}$ & $\mathrm{K}^{+}$ & $\mathrm{NH}_{4}^{+}$ & {$\left[\mathrm{NO}_{y}\right]^{\dagger}$} \\
\hline 14 (plume, 2.2 km) & 335 & 350 & 540 & 103 & 169 & 20 & 11 & 33 & 33 & 577 & 1030 \\
$14(4-5 \mathrm{~km})$ & 110 & 230 & 255 & 27 & 23 & 5 & $<1$ & 7 & 3 & 67 & 600 \\
$\Delta \mathrm{C}$ & 235 & 120 & 295 & 76 & 146 & 15 & 10 & 26 & 30 & 490 & 430 \\
23 (plume, 3-4 km) & 375 & 295 & 350 & 17 & 18 & 13 & $<1$ & $<10$ & 3 & 56 & 1150 \\
$23(3-5 \mathrm{~km})$ & 90 & 180 & 240 & 20 & 66 & 6 & $<1$ & 50 & 10 & 50 & 690 \\
$\Delta \mathrm{C}$ & 285 & 115 & 110 & -3 & -48 & 7 & $<1$ & $<-40$ & -7 & 6 & 460 \\
\hline
\end{tabular}

*Methane sulfonic acid.

†Total nitrogen oxides (gaseous and aerosol).

Peroxyacetyl nitrate (PAN) is an important reservoir for odd ni- । Hudson's Bay [Singh, 1991; Bradshaw et al., 1991] found NO in trogen, representing up to half the $\mathrm{NO}_{\mathrm{y}}$ above $4 \mathrm{~km}$ [Singh et al., this issue]. Much of the $\mathrm{NO}_{x}$ emitted by fires appears to be converted to PAN, which accounted for $30( \pm 5) \%$ of the NO, enhancement in haze layers (Table 1a). This efficient conversion to PAN can be explained by the low $\mathrm{NO}_{x}$ /hydrocarbon emission ratios in the fires and the low atmospheric temperatures [Jacob et al., this issue]. Decomposition of this PAN provided a small but potent source of $\mathrm{NO}_{x}$, mainly in warmer layers of the atmosphere at low altitude [Singh et al., this issue; Jacob et al., this issue].

Samples integrated over 30-60 min were obtained for gaseous acids and aerosols [Talbot et al., this issue] on Flights 14 and 23, in haze layers and in unperturbed air. Concentrations and enhancements are summarized in Table $1 b$. Concentrations of $\mathrm{HNO}_{3}$ were elevated by factors of 2-3 in the haze layers, accounting for 55 and $65 \%$ of the enhancement of $\mathrm{NO}_{y}$. The sum of PAN and $\mathrm{HNO}_{3}$ accounted for $-85 \%$ of $\mathrm{NO}_{y}$ on Flight 14, with the balance due to particulate $\mathrm{NO}_{3}^{-}$. Conversion of $\mathrm{NO}_{x}$ to reservoir species is evidently very rapid: recent results obtained near a smoke plume converted to nonradicals within minutes, apparently due to the overwhelming quantities of reactive hydrocarbons emitted by smoldering fires.

The aerosol data in Table $1 b$ show that the the haze layer in Flight 14 is rich in $\mathrm{NH}_{4}^{+}, \mathrm{K}^{+}$, and $\mathrm{Na}^{+}$. Ammonium more than offsets the acidity associated with $\mathrm{HNO}_{3}, \mathrm{HCOOH}$, and $\mathrm{CH}_{3} \mathrm{COOH}$, as observed also in haze layers attributed to Amazonian fires [Andreae et al., 1988] and in laboratory studies of smoldering fires [Lobert et al., 1991]. These observations support the view that large biomass fires may be recorded as spikes of ammonium and acetate in Greenland ice cores [Legrand et al., 1992].

Enhancements observed for $\mathrm{CH}_{4}, 0.17-0.23$ mole $\mathrm{CH}_{4} /$ mole $\mathrm{CO}$, were significantly higher than emission ratios observed in the laboratory from either flaming or smoldering combustion ([0.03 or $0.08 \mathrm{~mole} / \mathrm{mole}$, respectively [Lobert et al. 1991), in Amazon fires $(0.08$, [Greenberg et al., 1984]) or in boreal forest fires (0.097 [Cofer et al., 1989]). The data suggest that methane associated with tundra fires could represent in part biogenic methane 

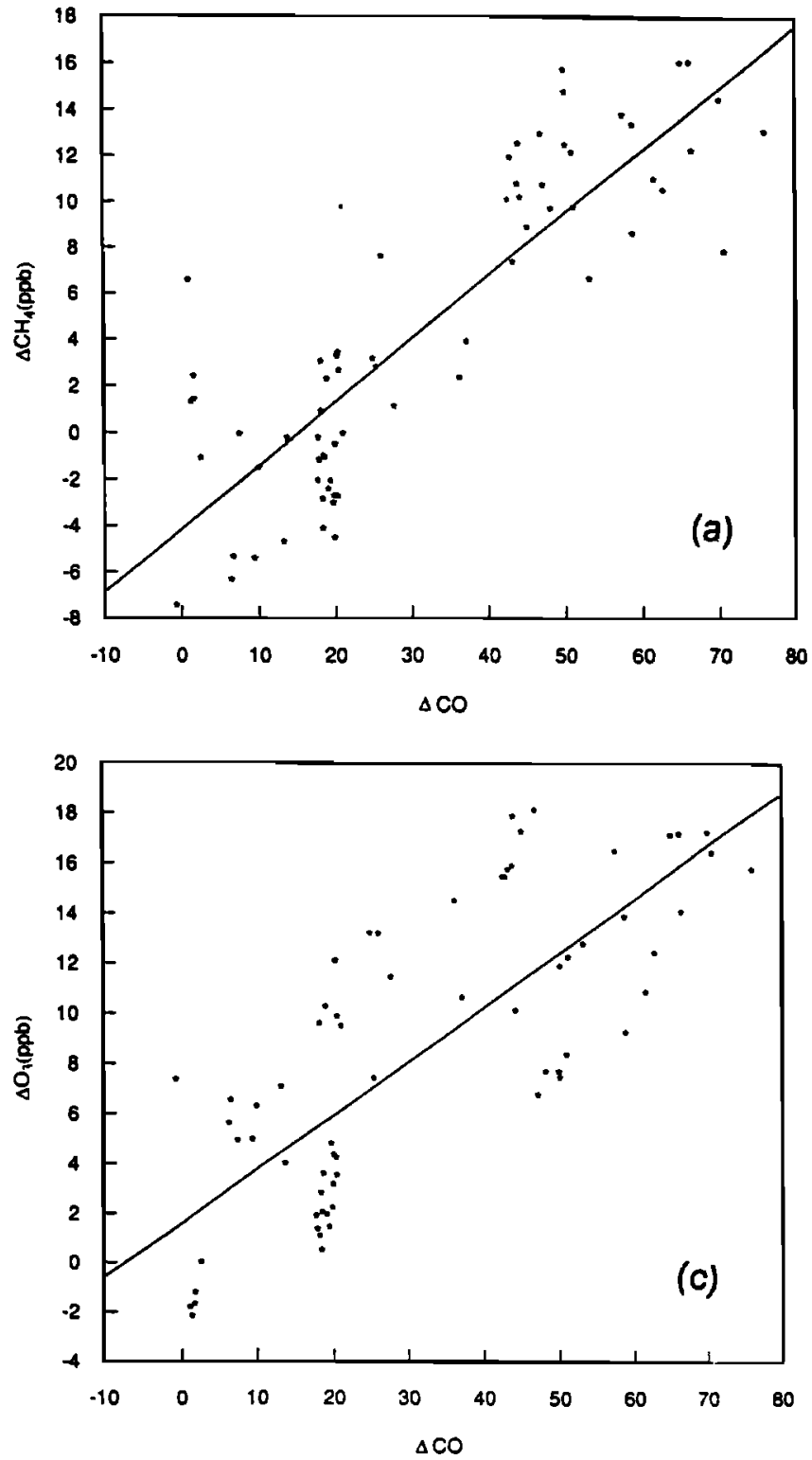

released from the ground, e.g., in response to heating. (Note that this $\mathrm{CH}_{4}$ would be depleted in ${ }^{13} \mathrm{C}$ relative to combustion-derived methane.)

The Electra encountered several layers with anomalous trace gas concentrations that did not appear to be from biomass fires, for example, on Flight 23 between 3 and $4 \mathrm{~km}$ (Table 1). Trajectory calculations suggest a distant source, in central Siberia, and pollution aerosols were absent (see Table $1 b$ ). However, NO levels were enhanced, consistent with recent emissions, and ozone was elevated as in Flight 14. The origin of the pollution observed in this area remains unclear.

Figure 6 shows anomalous data obtained during another flight, over the polar ice cap at $80^{\circ} \mathrm{N}$. Concentrations of $\mathrm{CH}_{4}$ and $\mathrm{CO}$ were markedly enhanced, and $\mathrm{O}_{3}$ apparently depressed. There were no data for $\mathrm{NO}_{\mathrm{y}}$ or hydrocarbons for this segment. It is apparent from Flight 33 (Table 2) that industrial pollution contains about twice as much methane, relative to $\mathrm{CO}$, as haze layers attributed to biomass buming. Conway and Steele [1989] and Hansen et al. [1989] previously reported a strong association of $\mathrm{CH}_{4}$ with combustion products over the high Arctic, and relatively fresh in-

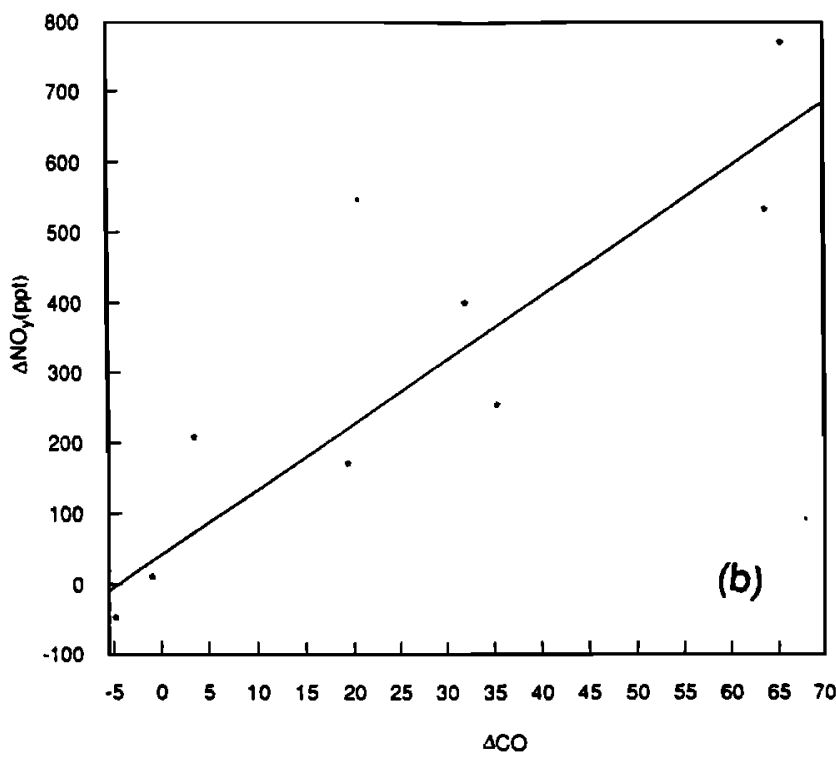

Fig. 5. Relationships between $\Delta \mathrm{CO}$ and $(a) \Delta \mathrm{CH}_{4},(b), \Delta \mathrm{NO}$, and (c) $\Delta \mathrm{O}_{3}$ for the haze layer encountered at point 1 on Flight 14 (Plate 1a).

dustrial pollutants were observed to be advected off the northeast coast of Canada during ABLE 3B [Blake et al., this issue]. The high $\Delta \mathrm{CH}_{4} / \Delta \mathrm{CO}$ ratio in Figure $6,0.5$, suggests episodic transport of industrial pollution to this remote area.

\section{3. $\mathrm{NO}_{x}, \mathrm{NO}_{y}$, AND HYDROCARBONS OVER THE EASTERN UNITED STATES}

Strong pollution influence was observed in the middle troposphere between Portland, Maine. and Wallops Island, Virginia., on Flight 33 (see Plate 1c), as summarized in Figure 7 and Table 2. Trajectories indicated probable origin from industrial midwestern regions [Shipham et al., this issue]. Polluted layers were rich in $\mathrm{CH}_{4}$ and $\mathrm{O}_{3}$ (both enhanced by 40-60 ppb) and in $\mathrm{CO}$ (elevated by $60-80 \mathrm{ppb}$ ), except in the boundary layer where ozone was apparently depleted by surface deposition. The average molar ratio $\Delta \mathrm{O}_{3} / \Delta \mathrm{CO}$ was 0.4 (excluding the boundary layer), similar to values observed elsewhere over the continental United States, [Pickering et al., 1989] and in marine areas influenced by pollution inputs [Fishman and Seiler, 1983; Chameides et al., 1987]. The average molar ratio $\Delta \mathrm{CH}_{4} / \Delta \mathrm{CO}$ was about 0.5 , twice as large as in Alaskan haze layers but similar to observations over the ice cap (Figure 6) and over the Bering Sea (Table 1).

Enhancements of $\mathrm{NO}_{\mathrm{y}}$ on Flight 33 were small, about $0.8 \mathrm{ppb}$ corresponding to 0.007 moles $\mathrm{N}_{\mathrm{y}} /$ mole $\mathrm{CO}$ (see Figure 7). Concentrations of $\mathrm{NO}_{x}$ were typically less than $100 \mathrm{ppt}$, and were not correlated with $C O$. The observed $\Delta \mathrm{NO}_{y} / \triangle \mathrm{CO}$ is much smaller than found near urban complexes [Parrish et al., 1991]. For example, at Niwot Ridge [Fahey et al., 1986], NO, concentrations exceeded $5 \mathrm{ppb}$ when $\mathrm{O}_{3}$ exceeded $70 \mathrm{ppb}$, nearly an order of

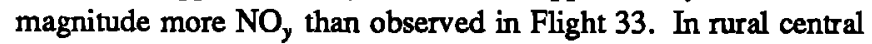
Massachusetts, $\Delta N O y / \Delta C O$ is typically $0.03-0.05$ when pollution is advected from New York City (J. W. Munger, P. S. Bakwin, B. C. Daube, S.-M. Fan, and S. C. Wofsy, unpublished data, 1992). Most of the ritrogen oxide radicals $\left(\mathrm{NO}_{x}\right)$ and $(-75 \%)$ of the $\mathrm{NO}_{y}$ were apparently removed in transit from industrial sources to the aircraft, demonstrating the potential for rapid oxidation followed by deposition. 
TABLE 2. Convariance Ratios (Relative to CO) Over the Northeastem United States (Flight 33)

\begin{tabular}{ccccccc}
\hline Flight Segment & $\mathrm{NO}_{y}$ & $\mathrm{C}_{2} \mathrm{H}_{2}$ & $\mathrm{C}_{2} \mathrm{H}_{6}$ & $\mathrm{C}_{3} \mathrm{H}_{8}$ & $\mathrm{CH}_{4}$ & $\mathrm{O}_{3}$ \\
\hline A 3-4 km & - & - & - & - & 0.48 & 0.32 \\
$\mathrm{~A} \mathrm{2.8-4.2 \textrm {km }}$ & - & - & - & - & 0.48 & 0.47 \\
$\mathrm{~A}<1.5 \mathrm{~km}$ & - & - & - & - & 0.55 & -0.16 \\
& & & & & & \\
$\mathrm{~B}>4.5 \mathrm{~km}$ & 0.0081 & 0.0017 & 0. & 0. & $0.57 ; 0.27$ & $0.63 ; 0.17$ \\
& & & & & & \\
C 1-4.5km & 0.0089 & 0.0017 & 0.037 & 0.015 & 0.76 & 0.43 \\
\hline
\end{tabular}

A, spiral departing from Portland; covariance of $\mathrm{CO}$ with $\mathrm{O}_{3}$ differed in the mixed layer from alttiutdes above;

$\mathrm{B}$, transit, Portland to Wallops Island; Two distinctly different values were noted for the covariance of $\mathrm{CH}_{4}$ and $\mathrm{O}_{3}$ with $\mathrm{CO}$, with higher values north of about $40^{\circ} \mathrm{N}$; C, descent into Wallops Island.
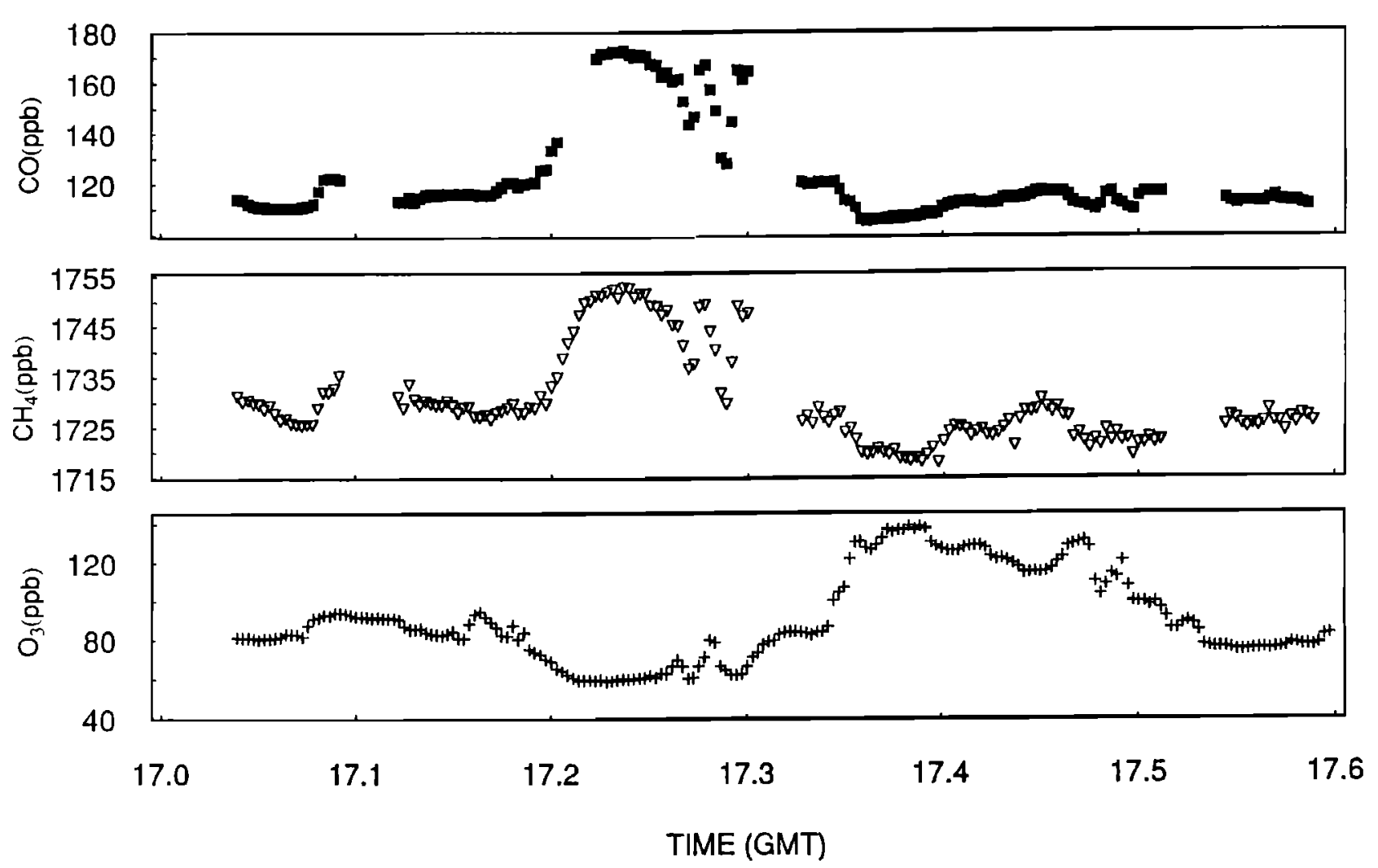

Fig. 6. Enhancernents of $\mathrm{CH}_{4}$ and $\mathrm{CO}$, and reduction of $\mathrm{O}_{3}$ observed during level flight at $80^{\circ} \mathrm{N}$ latitude over the polar ice cap on Flight 29. Concentrations of $\mathrm{H}_{2} \mathrm{O}$ were high [see also Gregory et al., this issue].

\section{Discussion}

Figure 8 shows average vertical profiles for the Bethel area, using data only for flights where no distinct haze layers were encountered $(11-13,15-17$, and 25$)$ to define the background atmospheric composition over sub-Arctic Alaska. Flights over the Bering Sea were not included, due to the pollution encountered there. Steep gradients, extending over the entire altitude range, were observed for $\mathrm{NO}_{y}$ (Figure 8a) and $\mathrm{O}_{3}$. Strong evidence indicates that vigorous stratosphere-troposphere exchange [Gregory et al., this issue; Browell et al., this issue; Danielsen and Hipskind, 1980] represents the dominant ozone source in this region during summer. Photochemical production of $\mathrm{O}_{3}$ is small or negative, in the background atmosphere and also in haze layers (see above and Jacob et al. [this issue]). We were unable to detect significant correlations between $\mathrm{O}_{3}$ and $\mathrm{CO}$ outside of haze layers (see Figures $8 \mathrm{~b}, 9 \mathrm{~b}$, and Gregory et al. [this issue]). These data differ markedly from aircraft observations over the North Pacific and the North Atlantic, which indicate positive correlations between $\mathrm{O}_{3}$ and CO [Fishman and Seiler, 1983; Fishman et al., 1987; Chameides et al., 1987, 1989; Marenco and Said, 1989].

Mean profiles for $\mathrm{CO}, \mathrm{C}_{2} \mathrm{H}_{2}$, and $\mathrm{C}_{2}-\mathrm{C}_{4}$ alkanes show signifi- 

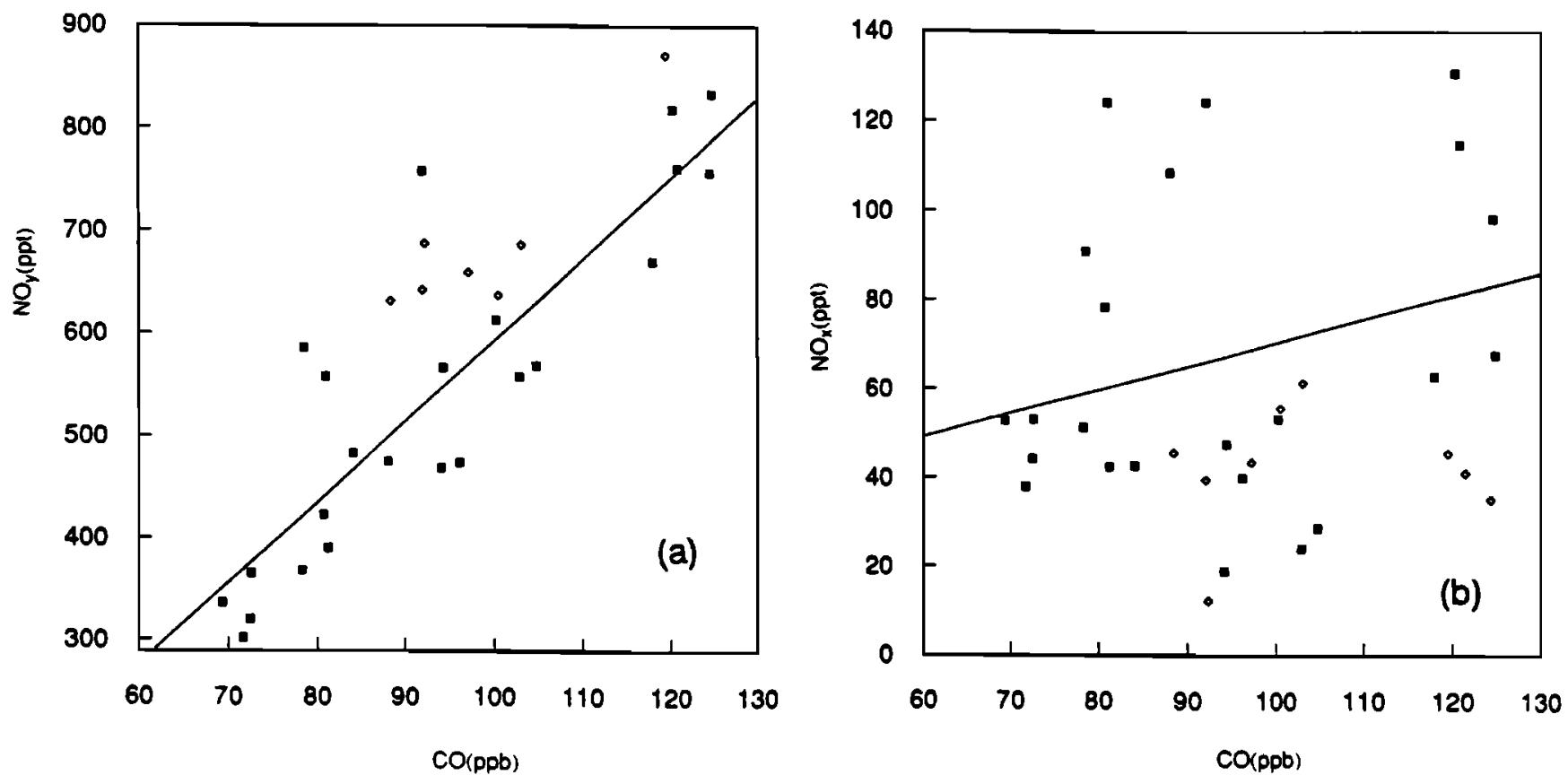

Fig. 7. Measurements of (a) $\mathrm{NO}_{y}(b)$ and $\mathrm{NO}_{x}$ observed during level flight above 4500-m altitude between Portland, Maine. and Wallops Island, Virginia. (solid squares), and during the descent into Wallops (open diamonds). The least squares line was fit to the data above $4500-\mathrm{m}$ only.

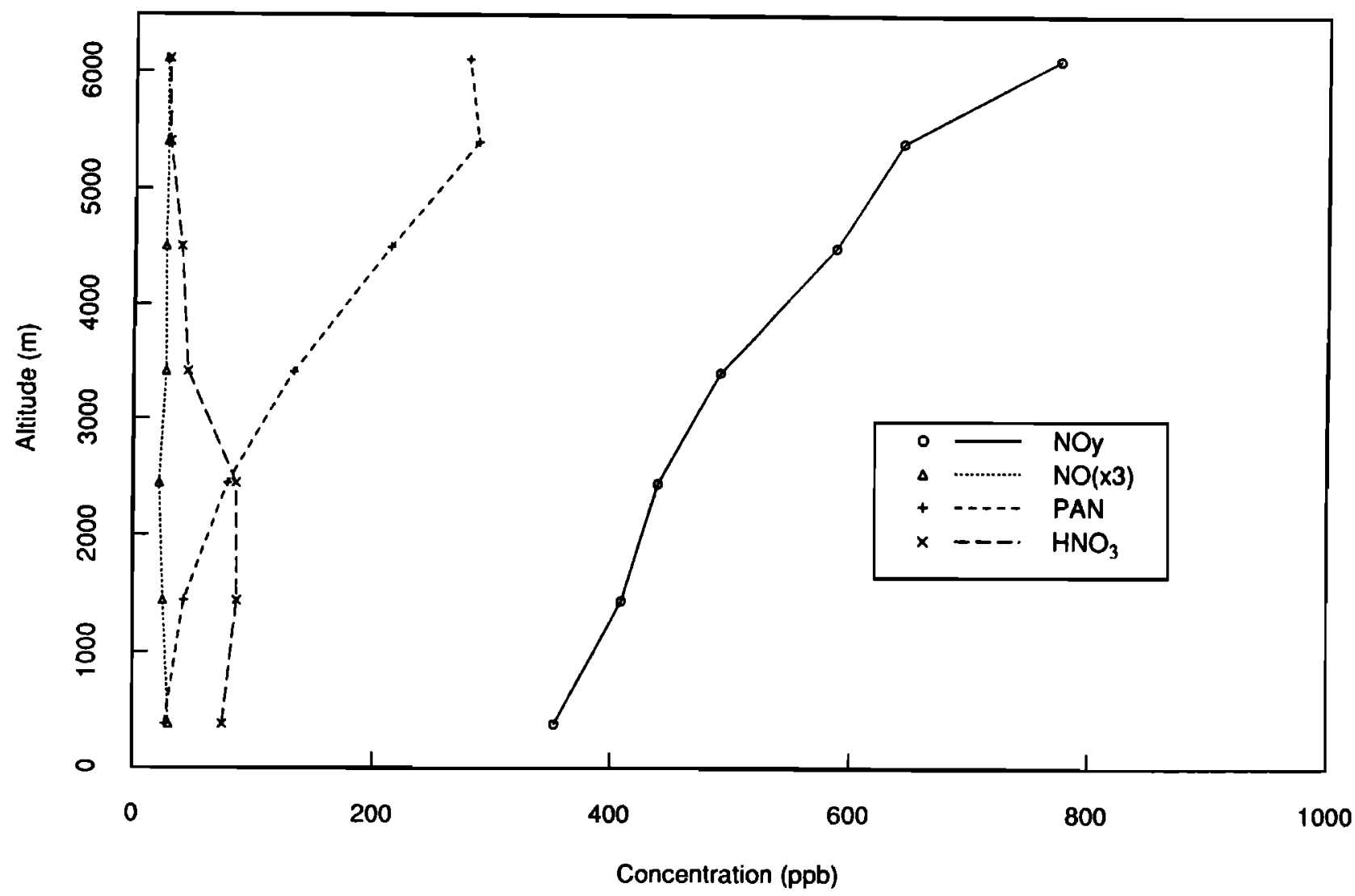

Fig. 8. Average vertical profiles for flights in the Bethel area defining "background" concentrations (11-13, 15-17, 25), excluding those where distinct haze layers were encountered $(14,20,21)$ : (a), nitrogen oxides (note NO scaled by factor 3); ( $b$ CO (ppb) and hydrocarbons (ppt) (note scaling of $\mathrm{C}_{2} \mathrm{H}_{6}$ ). 


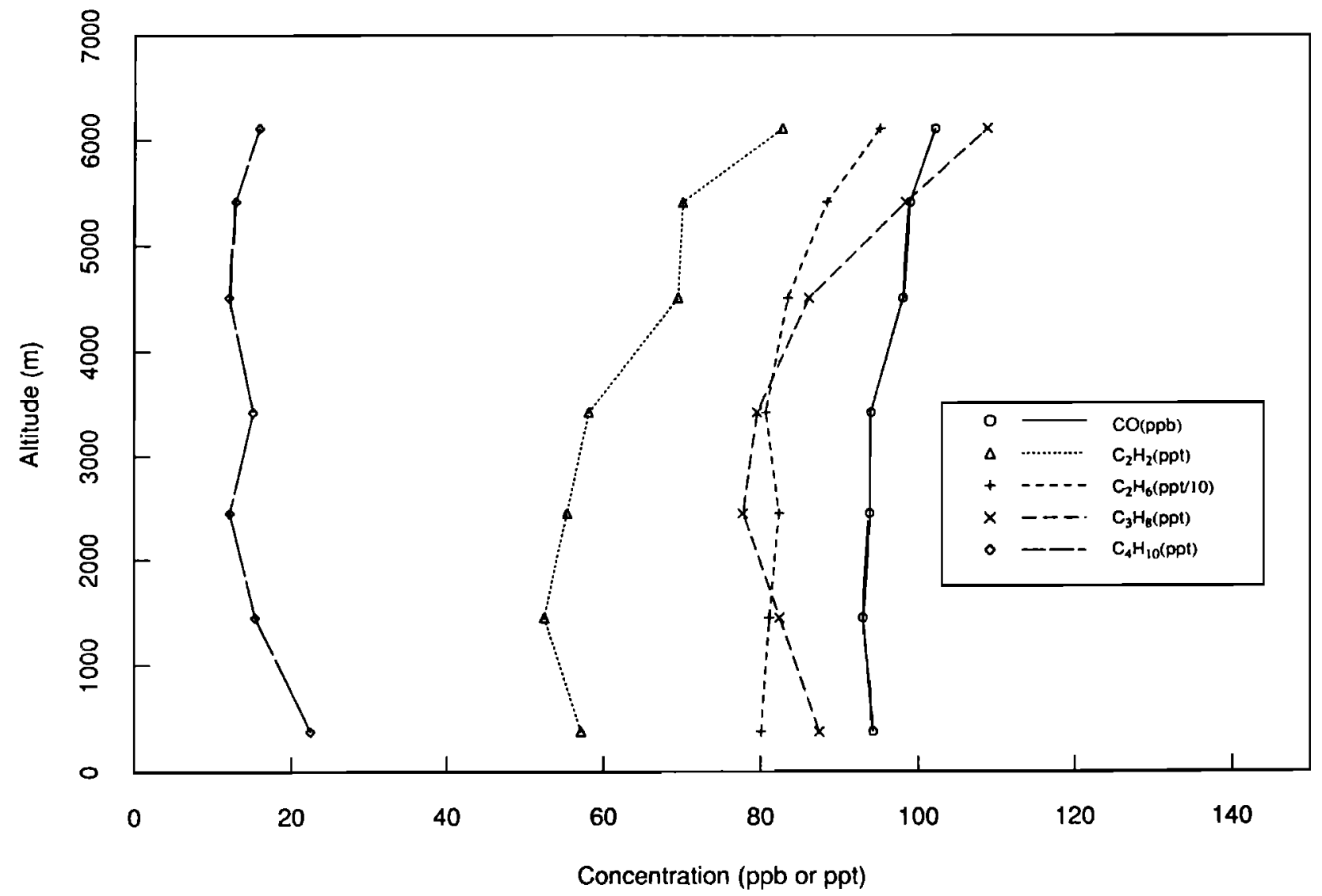

Fig. 8. (continued)

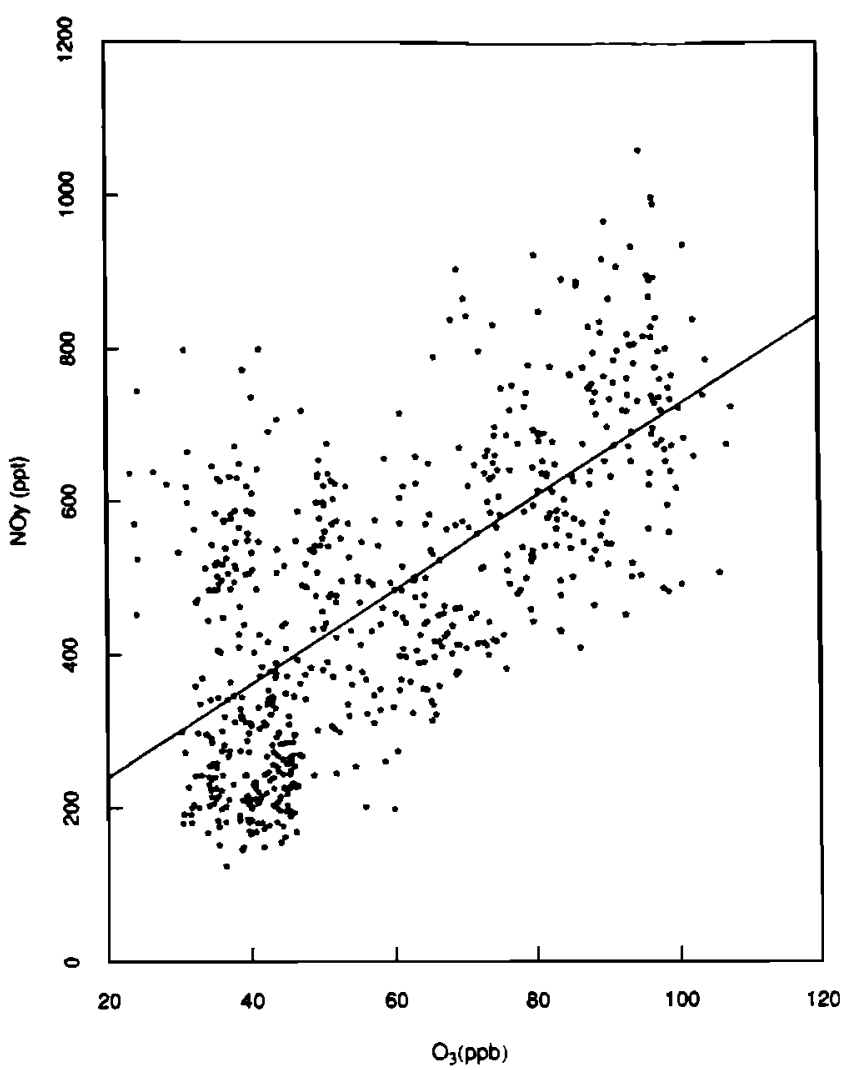

Fig. 9a. Scatterplot for NOy and $\mathrm{O}_{3}$ observed for all measurements on "background" Bethel flights (11-13, 15-17, 25). The regression line, $\mathrm{NO}_{y}(\mathrm{ppt})=118+6.05( \pm 0.26) \mathrm{O}_{3}(\mathrm{ppb})$, accounts for $44 \%$ of the variance.

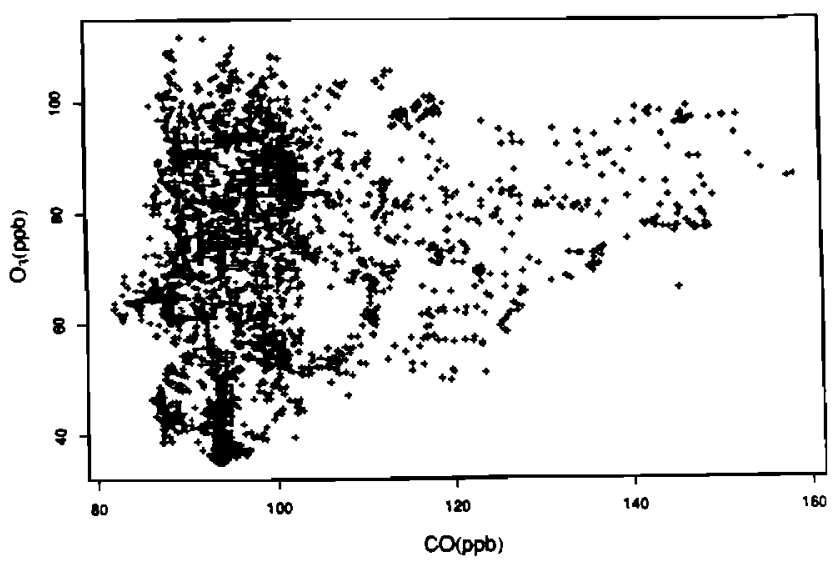

Fig. $9 b$. Scatterplot for $\mathrm{CO}$ against $\mathrm{O}_{3}$, for the flights above and altitudes > $3 \mathrm{~km}$. There is no significant correlation.

cant increase with altitude above $4 \mathrm{~km}$, in addition to suggestion of ground-level inputs. The stratosphere cannot be the source of hydrocarbons at altitude, and these C-shaped profiles indicate the influence of long-range transport of combustion by-products in the middle troposphere. The pattern of correlations between $\mathrm{CO}$, $\mathrm{CH}_{4}$, and alkanes suggests that boreal fires, arctic gas operations, and mid-latitude pollution could all contribute (see Table 3). Vertical profiles for gases with the longest lifetimes $\left(\mathrm{CO}, \mathrm{C}_{2} \mathrm{H}_{6}\right.$, $\mathrm{C}_{2} \mathrm{H}_{2}$ ) were nearly well-mixed, except when haze layers were present.

Correlations between concentrations of $\mathrm{NO}_{y}, \mathrm{NO}_{x}, \mathrm{O}_{3}$, and hydrocarbons can help us to evaluate relative contributions to back- 
TABLE 3. Relationships Among $\mathrm{NO}_{y}$, Hydrocarbons, $\mathrm{CO}$, and $\mathrm{O}_{3}$ (Equation (1))

\begin{tabular}{lcccc}
\hline \hline & \multicolumn{4}{c}{ Grabsample Subset } \\
\cline { 2 - 5 } Species & $\begin{array}{c}a_{1} \text { (ppt/ppb) } \\
\times \mathrm{O}_{3}\end{array}$ & $\begin{array}{c}a_{2} \text { (ppt/ppb) } \\
\times \mathrm{CO}\end{array}$ & $\mathrm{r}^{2 *}$ & Flights \\
\hline $\mathrm{NO}_{y}$ & $5.2( \pm 0.4)$ & $3.4( \pm 0.6)$ & $0.43[0.38]$ & $11-17,20,21,25$ \\
$\mathrm{C}_{2} \mathrm{H}_{6}$ & $1.6( \pm 0.4)$ & $6.0( \pm 0.14)$ & $0.74[0.27]$ & $\begin{array}{c}11-25 \\
\mathrm{C}_{2} \mathrm{H}_{2}\end{array}$ \\
$\mathrm{C}_{3} \mathrm{H}_{8}$ & $0.12( \pm 0.03)$ & $2.4( \pm 0.05)$ & $0.89[0.13]$ & (includes haze layers, \\
\hline $\mathrm{NO}_{y}$ & $5.1( \pm 0.04)$ & $1.6( \pm 0.09)$ & $0.5[0.10\}$ & no Bering Sea data) \\
\hline $\mathrm{NO}_{y}$ & $11.2( \pm 0.8)$ & $2.9( \pm 1.3)$ & $0.34[0.33]$ & $11-13,15-17,25$ (no haze, no Bering) \\
\hline
\end{tabular}

Full Data Set

\begin{tabular}{lcccc} 
& & & \\
Species & $a_{1}$ (ppt/ppb) & $a_{2}$ (ppt/ppb) & $\mathrm{r}^{2 *}$ & Flights \\
\hline $\mathrm{NO}_{y}$ & $5.7( \pm 0.27)$ & $4.0( \pm 0.7)$ & 0.47 & $11-13,15-17,25$ \\
$\mathrm{NO}_{y}$ & $6.05( \pm 0.26)$ & -- & {$[0.44]$} & (no haze, no Bering) \\
& & & & \\
$\mathrm{CH}_{4}$ & -- & 0.4 & 0.02 & \\
$\mathrm{CH}_{4}$ & -0.5 & 0.4 & 0.02 & \\
\hline $\mathrm{NO}_{y}$ & $5.5( \pm 1.3)$ & $-5.4( \pm 2.9)$ & 0.47 & $11-13,15-17,25$ (5-6 km only) \\
$\mathrm{NO}_{y}$ & $5.0( \pm 0.9)$ & -- & {$[0.38]$} & \\
$\mathrm{CH}_{4}$ & - & 1.1 & 0.58 & \\
\hline $\mathrm{NO}_{y}$ & $7.2( \pm 1.0)$ & -- & {$[0.91]$} & mean vertical gradient \\
\hline \hline
\end{tabular}

*Value for $r^{2}$, fraction of the variance removed by the two parameter fit. If in braces, $r^{2}$ for $\mathrm{O}_{3}$ the only independent variable.

ground levels that may be attributed to biomass fires, industrial emissions, and inputs from the stratosphere. If travel times are short compared to loss rates, ratios to $\mathrm{CO}$ should reflect the emission ratios for principal combustion sources. Correlation analysis cannot uniquely identify a source, since sinks can be quite different, as in the case of wet deposition which removes $\mathrm{NO}_{\mathrm{y}}$ but leaves $\mathrm{CO}$ unchanged. Nevertheless, near sources $\mathrm{CO}$ and $\mathrm{NO}_{\mathrm{y}}$ are correlated (see Figures 2,3,5b and 7a) and analysis of $\mathrm{NO}_{y} / \mathrm{CO}$ correlations provides useful constraints on possible sources of $\mathrm{NO}_{\mathbf{y}}$.

We examine correlations among various species measured over southern Alaska using the linear form

$$
Y=a_{0}+a_{1}\left[O_{3}\right]+a_{2}[\mathrm{CO}] \text {. }
$$

Here $Y$ is the concentration of the species, and the coefficients $a_{i}$ are determined by linear regression. The indicator species $\mathrm{CO}$ and $\mathrm{O}_{3}$ are uncorrelated (Figure $9 b$ ). If concentrations correlate strongly with $\mathrm{O}_{3}$, we suspect a contribution from the stratosphere, or perhaps from high-flying aircraft, while correlations with $\mathrm{CO}$ suggest a combustion component.

Table 3 shows best fit coefficients in Eq. (1) obtained using data for the Bethel area. The top panel of the table uses data corresponding to available hydrocarbon measurements (grab sample set, 130 data points), and the lower panel employs the larger subset (700 data points) with data available for $\mathrm{O}_{3}, \mathrm{CO}$, and $\mathrm{NO}_{y}$. Results are shown for "background" air (no identifiable haze layers on the flight: Flights 11-13, 15-17, 25), for "background" air plus flights with haze layers (14 and 20/21), but with data excluded from the haze layers themselves, and for all these flights including haze layer data. Flights over the Bering Sea are considered separately. Results in braces denote fits using only ozone as an independent variable, indicating how much of the variance $\left(r^{2}\right)$ is associated with $\mathrm{O}_{3}$.

Figure $9 a$ shows the correlation between $\mathrm{NO}_{y}$ and $\mathrm{O}_{3}$ for all "background" observations. As much as $30-45 \%$ of the variance of $\mathrm{NO}_{\mathrm{y}}$ is linearly related to $\mathrm{O}_{3}$ in the Bethel area, but there is no significant correlation with $\mathrm{CO}$. Particularly striking is the result for level flight legs at high altitude, where nearly half the variance can be explained by correlation with $\mathrm{O}_{3}$ alone (see rows labeled "5-6 km only" in the lower panel of Table 3). The average molar ratio, $\Delta \mathrm{NO} y / \Delta \mathrm{O}_{3}$, lies between 0.005 and 0.007 , strikingly close to the ratio in the lower stratosphere [Hubler et al., 1990; Kawa et al., 1990].

Input of $\mathrm{NO}_{\text {y }}$ from biomass fires could be detected on days when distinct haze layers were encountered (Table 1), but on other days, only a small part of the $\mathrm{NO}_{\mathrm{y}}$ variance was correlated with $\mathrm{CO}$. The behavior of $\mathrm{NO}_{\mathrm{y}}$ over southem Alaska contrasts with the hydrocarbons, all of which correlated strongly with $\mathrm{CO}$ but weakly, or not at all, with $\mathrm{O}_{3}$.

These results point to the stratosphere as an important source for $\mathrm{NO}_{\mathrm{y}}$ in this region, just as it is the main source of ozone [Danielsen and Hipskind, 1980; Gregory et al., this issue; Browell et al., this issue]. Levy et al. [1980] and Liu et al. [1980] proposed that the stratosphere should provide a major fraction of tropospheric $\mathrm{NO}_{y}$, while Logan [1983] and Kasibhatla et al. [1991] concluded that stratospheric input could account for only a small fraction of the $\mathrm{NO}_{\mathrm{y}}$ deposition flux at the surface. In ABLE $3 \mathrm{~A}$, the measured $\mathrm{NO}_{\text {y }}$ deposition flux was $2-5 \times 10^{9} \mathrm{~cm}^{-2} \mathrm{~s}^{-1}$ [Jacob et al., this issue; Bakwin et al., this issue], about 10x larger 
than the global mean flux of $\mathrm{NO}_{\mathrm{y}}$ from the stratosphere. Dry deposition, a major fraction of the total, occurs mostly over land, hence the mean stratospheric input could account readily for 15$20 \%$ of the total. Stratosphere-troposphere exchange at high latitudes is more vigorous than the mean [Browell et al., this issue; Danielsen and Hipskind, 1980], and it seems reasonable for the stratosphere to supply $40 \%$ or more of $\mathrm{NO}_{\mathbf{y}}$. Analysis of fire occurrence during the summer of 1988 indicated that $-30 \%$ of the regional deposition flux could be provided by $\mathrm{NO}_{y}$ from biomass fires [Jacob et al., this issue]. We argue therefore that $\mathrm{NO}_{\mathrm{y}}$ is provided mainly by stratospheric inputs and by biomass fires. If these inferences are correct the anthropogenic component of $\mathrm{NO}_{y}$ would be smaller than natural influences in this region during summer. We could rationalize this result by citing the rapid removal of industrial NO, demonstrated by the data from Flight 33 (Figure 7).

Singh et al. [this issue] argue that PAN, a major component of $\mathrm{NO}_{y}$, is influenced by combustion. This interpretation is not necessarily inconsistent with our analysis; PAN may well derive from hydrocarbons released by pollution or biomass buming, while the inorganic component of $\mathrm{NO}_{y}$ may originate from the stratosphere. Haze layers attributed to tundra fires are certainly very rich in PAN, and they are found at the altitudes where PAN concentrations peak. Nitric acid is also produced efficiently in the haze layers but would have a short lifetime against deposition. Assessment of factors influencing $\mathrm{NO}_{\mathrm{y}}$ is inhibited by the fragmentary understanding of NOy chemistry in the troposphere. Concentrations of $\mathrm{HNO}_{3}$ are low, and major components of $\mathrm{NO}_{y}$ remain unidentified.

Methane concentrations at high altitude were strongly correlated with $\mathrm{CO}\left(r^{2}=0.58\right)$, with a molar ratio of 1.1 moles $\mathrm{CH}_{4} /$ mole $\mathrm{CO}$, but were uncorrelated with $\mathrm{O}_{3}$ (Table 3 , lower panel). This ratio was more than 5 times larger than observed from tundra fires, suggesting an input from $\mathrm{CH}_{4}$-rich industrial sources such as gas fields or mid-latitude pollution. Mean concentrations of propane increased by about $20 \mathrm{ppt}$ where CO rose by only 5-7 ppb, corresponding also to a source rich in alkanes. There was no significant correlation between $\mathrm{CH}_{4}$ and $\mathrm{CO}$ in the boundary layer, where biogenic sources of $\mathrm{CH}_{4}$ were dominant [e.g., Bartlett et al., this issue].

\section{ConClusions}

Haze layers apparently associated with boreal fires were enriched in hydrocarbons and $\mathrm{NO}_{y}$, with emission factors corresponding closely to laboratory data for smoldering combustion. We argue that atmospheric composition was strongly modified by wild fires during several periods of the ABLE 3A mission. The associated enhancement of $\mathrm{NO}_{y}$ was smaller than observed for most other combustion processes, but was nonetheless significant in the context of very low background concentrations.

Ozone production in fire plumes was negligible because $\mathrm{NO}_{x}$ emissions were low and because $\mathrm{NO}_{x}$ was rapidly oxidized to $\mathrm{HNO}_{3}$ and PAN. Eventual decomposition of pyrogenic PAN in the regional atmosphere may have a widespread effect on $\mathrm{O}_{3}$ levels by slowing down the rate of photochemical loss [Jacob et al., this issue]. The low $\mathrm{NO}_{x} / \mathrm{CO}$ emission ratio suggests that tundra fires could depress $\mathrm{OH}$ concentrations on the regional scale.

Ambient $\mathrm{O}_{3}$ was supplied by the stratosphere, with little direct input from mid-latitude sources during summer. We argued that $\mathrm{NO}_{\mathrm{y}}$ was supplied about equally by the stratosphere and by wildfires. Hydrocarbons and $\mathrm{CO}$ appear to derive from biomass fires and from human activities, including gas extraction in the Arctic and long-range transport of mid-latitude pollution. Anthropogenic inputs of hydrocarbons may shift the speciation of $\mathrm{NO}_{y}$ toward
PAN, thus facilitating long-range transport of $\mathrm{NO}_{y}$ with resulting perturbation to $\mathrm{NO}_{x}$ in the remote atmosphere [Crutzen, 1979; Kasting and Singh, 1986].

If areas burned in tundra fires increase, as noted in response to climate warming in northem Ontario between 1960 and 1990 [Schindler et al., 1990], enhancements might be expected in levels of $\mathrm{O}_{3}$ and $\mathrm{NO}_{y}$. Should climate warm in response to global increases in greenhouse gases, we can expect increased fires and associated perturbations to oxidant and aerosol chemistry to be among the diverse environmental impacts.

Acknowledgments. This work was supported by NASA grants to participating institutions for ABLE 3A, by NSF grants ATM 84-13153 and 89-21119 to Harvard University, and by the Packard Foundation.

\section{REFERENCES}

Andreae, M. O., et al., Biomass-burning emissions and associated haze layers over Amazonia, J. Geophys. Res., 93, 1509-1527, 1988.

Bakwin, P. S., S. C. Wofsy, S. -M. Fan, and D. R. Fitzjarrald, Measurements of $\mathrm{NO}_{x}$ and NO concentrations and fluxes over Arctic tundra, $J$. Geophys. Res., this issue.

Barrie, L. A., and R. M. Hoff, Five years of air chemistry observations in the Canadian Arctic, Atmos. Environ., 1995-2010, 1985.

Bartlett, K. B., P. M. Crill, R. L. Sass, R. C. Harriss, and N. B. Dise, Methane emissions from tundra environments in the Yukon-Kuskokwim Delta, Alaska, J. Geophys. Res., this issue.

Blake, D. R., D. F. Hurst, T. W. Smith, Jr., W. J. Whipple, T. -Y. Chen, N. J. Blake, and F. S. Rowland, Summertime measurements of selected nonmethane hydrocarbons in the Arctic and sub-Arctic during the 1988 Arctic Boundary Layer Expedition (ABLE 3A), J. Geophys. Res., this issue.

Bradshaw, J.D., R.W. Talbot, H.B. Singh, D.R. Blake, G.W. Sachse, and A. Bachmeier, Summertime tropospheric distribution of reactive oddnitrogen compounds over Canada, Eos Trans. AGU, 7274, 1991.

Browell, E. V., C. F. Butler, S. A. Kooi, M. A. Fenn, R. C. Harriss, and G. L. Gregory, Large-scale variability of ozone and aerosols in the summertime arctic and subarctic troposphere, J. Geophys. Res., this issue.

Chameides, W. L., D. D. Davis, M. O. Rodgers, J. Bradshaw, S. Sandholm, G. Sachse, G. Hill, G. Gregory, and R. Rasmussen, Net ozone photochemical production over the eastem and central North Pacific as inferred from GTE/CITE 1 observations during fall 1983, J. Geophys. Res., 92, 2131-2152, 1987.

Chameides, W. L., D. D. Davis, G. L. Gregory, G. Sachse, and A. L. Torres, Ozone precursors and ozone photochemistry over eastern north Pacific Ocean during spring 1984, J. Geophys. Res., 94, 9799-9808, 1989.

Chapin, F.S., III., and G.R. Shaver, Arctic, in Physiological Ecology of North American Plant Communities, edited by B. F. Chabot and H. A. Mooney, Chapman and Hall, New York, 1985.

Cofer, W. R. III, J. S. Levine, P. J. Riggan, D. I. Sebacher, E. L. Winstead, E. F. Shaw, J. A. Brass, and V. G. Ambrosia, Trace gas emissions from a mid-latitude chaparral fire, J. Geophys. Res., 93, 1653-1658, 1988.

Cofer, W. R., III, J. S. Levine, D. I. Sebacher, E. L. Winstead, P. J. Riggan, B. J. Stocks, J. A. Brass, V. G. Ambrosia, and P. J. Boston, Trace gas emissions from chaparral and boreal forest fires, J. Geophys. Res, 94, 2255-2259, 1989.

Conway, T. J., and L. P. Steele, Carbon dioxide and methane in the Arctic atmosphere, J. Atmos. Chem., 9, 81-100, 1989.

Crutzen, P. J., The role of $\mathrm{NO}$ and $\mathrm{NO}_{2}$ in the chemistry of the troposphere and stratosphere, Annu. Rev. Earth Planet. Sci.7, 443-472, 1979.

Crutzen, P. J., and M. O. Andreae, Biomass buming in the tropics: Impact on atmospheric chemistry and biogeochemical cycles, Science, 250, 1669-1678, 1990.

Crutzen, P. J., A. C. Delany, J. Greenberg, P. Haagenson, L. Heidt, R. Lueb, W. Pollock, W. Seiler, A. Wartburg, and P. Zimmerman, Tropos- 
pheric chemical composition measurements in Brazil during the dry season, J. Atmos. Chem., 2,233-256, 1985.

Danielsen, E. F., and R. S. Hipskind, Stratospheric-tropospheric exchange at polar latitudes in summer, J. Geophys. Res, 85, 393-400, 1980.

Fahey, D. W., G. Hubler, D. D. Parrish, E. J. Williams, R. B. Norton, B. A. Ridley, H. B. Singh, S. C. Liu, and F. C. Fehsenfeld, Reactive nitrogen species in the troposphere: Measurements of $\mathrm{NO}_{1} \mathrm{NO}_{2}, \mathrm{HNO}_{3}$, particular nitrate, peroxyacetyl nitrate (PAN), $\mathrm{O}_{3}$, and total reactive nitrogen (NO at Niwot Ridge, Colorado, J. Geophys. Res., 91, 9781-9793, 1986.

Fishman, J., and W. Seiler, Correlative nature of ozone and carbon monoxide in the troposphere: Implications for the tropospheric ozone budget, J. Geophys. Res, 88, 3662-3670, 1983.

Fishman, J., G. L. Gregory, G. W. Sachse, S. M. Beck, and G. F. Hill, Vertical profiles of ozone, carbon monoxide, and dew-point temperature obtained during GTE/CITE 1, October-November 1983, J. Geophys. Res., 92, 2083-2094, 1987.

Greenberg, J. P., P. R. Zimmerman, L. Heidt, and W. Pollock, Hydrocarbon and carbon monoxide emissions from biomass buming in Brazil, $J$. Geophys. Res, 89, 1350-1354, 1984.

Gregory, G. L., B. E. Anderson, L. S. Warren, E. V. Browell, D. R. Bagwell, and C. H. Hudgins, Tropospheric ozone and aerosol observations: The Alaskan Arctic, J. Geophys, Res., this issue.

Hansen, A. D. A., T. J. Conway, L. P. Steele, B. A. Bodhaine, K. W. Thoning, P. Tans, and T. Novakov, Correlations among combustion effluent species at Barrow, Alaska: Aerosol black carbon, carbon dioxide, and methane, J. Atmos. Chem., 9, 283-299, 1989.

Harriss, R. C., G. W. Sachse, G. F. Hill, L. Wade, K. B. Bartlett, J.E. Collins, L. P. Steele, and P. Novelli, Carbon monoxide and methane in the North American Arctic and sub-Arctic troposphere: July-August 1988, J. Geophys. Res, this issue.

Hegg, D. A., L. F. Radke, P. V. Hobbs, R. A. Rasmussen, and P. J. Riggan, Emissions of trace gases from some biomass fires, $J$. Geophys. Res., 95, 5669-5675, 1990.

Hubler, G., D. W. Fahey, K. K. Kelly, D. D. Montzka, M. A.Carroll, A.F. Tuck, L. E. Heidt, W. H. Pollock, G. L. Gregory, and J. F. Vedder, Redistribution of reactive odd nitrogen in the lower arctic stratosphere, Geophys. Res. Lett., 17, 453-456, 1990.

Jacob, D. J., et al., Summertime photochemistry of the troposphere at high northem latitudes, J. Geophys. Res., this issue.

Kasibhatla, P. S., H. Levy II, W. J. Moxim, and W. L. Chameides, The relative impact of stratospheric photochemical production on tropospheric NO levels: A model study, J. Geophys. Res., 96, 18,631-18,646, 1991.

Kasting, J. F., and H. B. Singh, Nonmethane hydrocarbons in the troposphere: Impact on the odd hydrogen and odd nitrogen chemistry, $J$ Geophys. Res., 91, 13,239-13,256, 1986.

Kawa, S. R., D. W. Fahey, L. C. Anderson, M. Lowenstein, and K. R. Chan, Measurements of total reactive nitrogen during the Airbome Arctic Stratospheric Expedition, Geophys. Res. Lett., 17, 495-488, 1990.

Legrand, M., M. De Angelis, T. Staffelbach, A. Neftel, and B. Stauffer, Large perturbations of ammonium and organic acid contents in the Summit-Greenland ice core: Fingerprint from forest fires?, Geophys. Res. Lett., 19, 473-495, 1992.

Levy, H., II, J. D. Mahlman, and W. J. Moxim, A stratospheric source of reactive nitrogen in the unpolluted troposphere, Geophys. Res. Lett., 7, $441-444,1980$.

Liu, S.-C., D. Kley, M. McFarland, J. D. Mahlman, and H. Levy II, On the origin of tropospheric ozone, J. Geophys. Res. 85, 7546-7552, 1980.

Liu, S. C., M. Trainer, F. C. Fehsenfeld, D. D. Parrish, E. J. Williams, D. W. Fahey, G. Huebler, and P. C. Murphy, Ozone production in the rural troposphere and the implications for regional and global ozone distributions, J. Geophys. Res., 92, 4191-4207, 1987.
Lobert, J. M., D. H. Scharffe, W. M. Hao, T. A. Kuhlbusch, R. Scuwen, P. Wameck, and P. J. Crutzen, Experimental evaluation of biomass buming emissions: Nitrogen and carbon containing compounds, in Global Biomass Burning, edited by J. S. Levine, pp. 289-304, MTT Press, Cambridge, Mass., 1991.

Logan, J. A., Nitrogen oxides in the troposphere: Global and regional budgets, J. Geophys. Res., 88, 10,785-10,807, 1983.

Marenco, A., and F. Said, Meridional and vertical ozone distribution in the background troposphere $\left(70^{\circ} \mathrm{N}-60^{\circ} \mathrm{S} ; 0-12 \mathrm{~km}\right.$ altitude) from scientific aircraft measurements during the STRATOZ III experiment (June 1984), Atmos. Environ., 23, 201-214, 1989.

Parrish, D. D., M. Trainer, M. P. Buhr, B. A. Watkins, and F. C. Fehsenfeld, Carbon monoxide concentrations and their relation to concentrations of reactive oxidized nitrogen at two rural U.S. sites, J. Geophys. Res., 96, 9309-9320, 1991.

Pickering, K. E., R. R. Dickerson, W. T. Luke, and L. J. Nunnermacker, Clear-sky vertical profiles of trace gases influenced by upstream convective activity, J. Geophys. Res., 94, 14,879-14,892, 1989.

Rahn, K. (Ed.), Arctic air chemistry, Atmos. Environ., 15, 8-215, 1981.

Rahn, K. A., and R. J. McCaffrey, On the origin and transport of the winter arctic aerosol. Ann. N. Y. Acad. Sci., 77, 486-503, 1980.

Schindler, D. W., K. G. Beaty, E. J. Fee, D. R. Cruikshank, E. R. DeBruyn, D. L. Findlay, G. A. Linsey, J. A. Schearer, M. P. Stanton, and M. A. Tumer, Effects of climatic warming on lakes of the central boreal forest, Science, 250, 967-970, 1990.

Seiler, W. and P. J. Crutzen, Estimates of gross and net flux of carbon between the biosphere and atmosphere from biomass buming, Clim. Change, 2, 226-247, 1980.

Shipham, M. C., A. S. Bachmeier, D. R. Cahoon, Jr., and E. V. Browell, Meteorological overview of the Arctic Boundary Layer Expedition (ABLE 3A) flight series, J. Geophys. Res., this issue.

Singh, H. B. Reactive nitrogen distribution and photochemistry during ABLE 3B, Eos Trans., AGU, 72, 74, 1991.

Singh, H. B., D. O'Hara, D. Herlth, J. D. Bradshaw, S. T. Sandholm, G. L. Gregory, G. W. Sachse, and D. R. Blake, Atmospheric measurements of peroxyacetyl nitrate and other organic nitrates at high latitudes: Possible sources and sinks, J. Geophys. Res., this issue.

Talbot, R. W., A. S. Vygen, and R. C. Harris, Soluble species in the Arctic summer troposhere: Acidic gases, aerosols, and precipitation, J. Geophys. Res., this issue.

Ward, D. E., and C. C. Hardy, Smoke emissions from wildland fires. Environ. Int. 17, 117-134, 1991.

J. A. Barrick, E. V. Browell, G. L. Gregory, G. W. Sachse, and M. A. Shipman, NASA Langley research Center, Hampton, VA 22331.

D. R. Blake, Department of Chemistry, University of Califomia at Irvine, Irvine, CA 92717.

J. D. Bradshaw and S. T. Sandholm, School of Earth and Atmospheric Science, Georgia Institute of Technology, Atlanta, GA 30332.

R. C. Harriss and R. W. Talbot, Complex Systems research Center, University of New Hampshire, Durham, NH 03814.

D. J. Jacob, J. A. Logan, and S .C. Wof sy, Division of Applied Sciences and Department of Earth and Planetary Science, Harvard University, Cambridge, MA 02138.

H. B. Singh, NASA Ames research Center, Moffett Field, CA 94035.

(Received January 17, 1991;

revised March 12, 1992;

accepted March 12, 1992.) 